\title{
Synergistic apoptotic effects of taurolidine and TRAIL on squamous carcinoma cells of the esophagus
}

\author{
ADRIEN DAIGELER $^{1,2^{*}}$, ANSGAR MICHAEL CHROMIK $^{1 *}$, ANNE GEISLER $^{1}$, \\ DANIEL BULUT ${ }^{3}$, CHRISTOPH HILGERT $^{1}$, ANDREAS KRIEG ${ }^{4}$, LUDGER KLEIN-HITPASS ${ }^{5}$, \\ MARCUS LEHNHARDT ${ }^{2}$, WALDEMAR UHL ${ }^{1}$ and ULRICH MITTELKÖTTER ${ }^{1}$
}

\author{
${ }^{1}$ Department of General and Visceral Surgery, St. Josef Hospital, Ruhr-University, Gudrunstrasse 56, D-44791 Bochum; \\ ${ }^{2}$ Department of Plastic Surgery, Burn Center, Hand Center, Sarcoma Reference Center, BG-University Hospital \\ Bergmannsheil, Bürkle-de-la-Camp-Platz 1, D-44789 Bochum; ${ }^{3}$ Department of Medicine II, St. Josef Hospital, \\ Ruhr-University, Gudrunstrasse 56, D-44791 Bochum; ${ }^{4}$ Department of Surgery, Heinrich Heine-University, \\ Moorenstrasse 5, D-40225 Duesseldorf; ${ }^{5}$ Institute for Cell Biology (Tumor Research), \\ University of Duisburg-Essen, Virchowstrasse 173, D-45122 Essen, Germany
}

Received January 7, 2008; Accepted March 5, 2008

\begin{abstract}
The treatment of choice for esophageal cancer is considered surgical resection, but a median survival of around 20 months after treatment is still discouraging. The value of adjuvant or neoadjuvant radiation or chemotherapy is limited and to date, benefits have only been described for certain tumor stages. Therefore, new therapeutic options are required. As alternative chemotherapeutics, we tested the antibiotic taurolidine (TRD) on KYSE 270 human esophageal carcinoma cells alone and in combination with rhTRAIL (TNF related apoptosis-inducing ligand). Viability, apoptosis and necrosis were visualized by TUNEL assay and quantitated by FACS analysis. Gene expression was analysed by RNA microarray. The most effective concentration of TRD as single substance $(250 \mu \mathrm{mol} / \mathrm{l})$ induced apoptosis to a maximum of $40 \%$ after 12-h dose dependently, leaving $4 \%$ viable cells after $48 \mathrm{~h}$; by comparison, rhTRAIL did not have a significant effect. The combination of both substances doubled the effect of TRD alone. Gene expression profiling revealed that TRD downregulated endogenous TRAIL, TNFRSF1A, TRADD, TNFRSF1B, TNFRSF21, FADD, as well as MAP2K4, JAK2 and Bcl2, Bcl211, APAF1 and caspase-3. TNFRSF25, cytochrome-c, caspase-1, -8, -9, JUN, GADD45A and NFKBIA were upregulated. TRAIL
\end{abstract}

Correspondence to: Dr Adrien Daigeler, Department of Plastic Surgery, BG-University Hospital Bergmannsheil, Bürkle-de-laCamp-Platz 1, D-44789 Bochum, Germany

E-mail: adrien.daigeler@rub.de

${ }^{*}$ Contributed equally

Key words: taurolidine, tauroline, apoptosis, esophagus carcinoma, TRAIL, NFKB reduced endogenous TRAIL, Bcl211 and caspase-1 expression. BIRC2, BIRC3, TNFAIP3, and NFKBIA were upregulated. The combined substances upregulated endogenous TRAIL, NFKBIA and JUN, whereas DFFA and TRAF3 were downregulated compared to TRD as single substance. We conclude that TRD overcomes TRAIL resistance in KYSE 270 cells. Synergistic effects are dependent on the same and on distinct apoptotic pathways which, jointly triggered, result in an amplified response. Several apoptotic pathways, including the TNF-receptor associated and the mitochondrial pathway, were differentially regulated by the substances on gene expression level. Additionally transcription factors seem to be influenced, NFKB in particular. Endogenous TRAIL expression is increased by the combination of substances, whereas it is reduced by each single substance. Taking into consideration that the non-toxic TRD was able to reduce rhTRAIL toxicity and dose, combined therapy with TRD and rhTRAIL may offer new options for treatment in esophageal cancer.

\section{Introduction}

The carcinoma of the esophagus with a stage dependent survival of rarely $>50 \%$ still represents a therapeutic challenge especially concerning the fact that its incidence is rising. Treatment of esophageal carcinoma is based on individualised and stage specific multimodal approaches which comprise esophagectomy as well as neoadjuvant, adjuvant or palliative chemotherapy and radiation. Despite this broad multidisciplinary armamentarium, the overall survival is still poor and problems such as primary or acquired resistance against chemotherapy or side effects remain unsolved (1-8). New treatments such as immunotherapy and hyperthermia so far have also failed to improve the outcome significantly (914). For unresectable tumors the effects of chemotherapy and radiotherapy may prolong survival in some cases, but side effects are severe and life quality remains poor (15-18). 
To elucidate new options for treatment we tested two promising agents rhTRAIL (recombinant human tumor necrosis factor associated apoptosis inducing ligand) and taurolidine (TRD) seperately and in combination on esophageal squamous cancer cells (KYSE 270) in vitro.

TRAIL as a physiological apoptosis inducing molecule of $33 \mathrm{kD}$ belongs to the TNF super-family and seems to be involved in the natural antitumoral and antiviral immunoresponse (19). TRAIL initiates cell death by binding to the transmembraneous death receptors 4 and 5 (DR4, DR5), thereby inducing the binding of the intracellular adaptor molecule FADD (Fas associated death domain) and starting a cascade involving caspase- 8 to form the so-called DISC (death-inducing signalling complex) which is activating several effector caspases. Another type of cell death induction by TRAIL via the intrinsic, mitochondrial pathway leading to a cytochrome-c efflux from mitochondria, formation of apoptosomes and activation of the effector caspases has also been described (19-26). In contrast to many other chemotherapeutics, TRAIL induces apoptosis independently from p53 $(21,27,28)$. Binding of TRAIL to the decoy receptors 1 and 2 (DcR1, DcR2) that, in contrast to DR4 and DR5, lack a transmembraneous death domain, probably results in a competitive inhibition of apoptosis $(19,29)$. Several recombinant versions of TRAIL have been generated and some were shown to induce apoptosis in healthy hepatocytes and keratinocytes $(30,31)$. In contrast, a new recombinant human TRAIL (rhTRAIL) without any added exogenous sequences has been shown to be well tolerated by mice and non-human primates without relevant side effects (20,32). Many substances, including established chemotherapeutics such as 5-Fluorouracil, cisplatin, doxorubicin, etoposide, have been shown to sensitize tumor cells including esophageal cancer cells to TRAIL-induced apoptosis probably by increased DR4 and DR5 expression, improved DISC formation and other mechanisms (33-39).

Taurine is a semi-essential amino acid and is not incorporated into proteins. In mammalian tissues, taurine is ubiquitous and is the most abundant free amino acid in the heart, retina, skeletal muscle, brain and leukocytes. It protects normal tissue from oxidant-induced injury and apoptosis (40). TRD, derived from Taurine, originally was used as an antimicrobial and antiinflammatory substance in the treatment of peritonitis and blood stream infections without any observed short- or long-term toxicity (41-43). Recent studies revealed an apoptotic effect on a variety of malignant cells in vitro and in vivo, including colon, ovarian, prostate carcinoma, melanoma, mesothelioma, osteosarcoma and leukemia (44-52). First reports of successful treatments of glioblastoma and gastric cancer without systemic side effects in humans are promising (53-55). The detailed mechanism of action is still unclear, but inhibition of Bcl-2 and an increased efflux of cytochrome-c, activation of the caspases, and an increased PARP (poly(ADP-ribose) polymerase) cleavage seem to be involved $(44,48,49,51,52,56)$. By comparison, other authors found Fas-ligand dependent mechanisms or inhibition of tumor angiogenesis to be responsible for the inhibition of tumor growth (57-59).

The absence of toxicity and its apoptosis inducing potential make TRD a candidate for co-treatment with TRAIL, hypothetically increasing its apoptotic effects. To our knowledge, a combination of rhTRAIL and TRD has not yet been investigated on esophageal cancer cells.

\section{Materials and methods}

Cell line. Human esophageal squamous cancer cells, Kyse 270, were purchased from DSMZ (Braunschweig, Germany) and maintained with $48 \%$ RPMI-1640 + 48\% Ham's F12 + $2 \%$ FBS supplemented with $1 \%$ penicillin $(100 \mathrm{U} / \mathrm{ml})$ and streptomycin $(100 \mu \mathrm{g} / \mathrm{ml})$ and $1 \%$ L-Glutamine. Cells were cultured in a humidified atmosphere with $5 \% \mathrm{CO}_{2}$ at $37^{\circ} \mathrm{C}$ on 6-well plates with $1 \times 10^{6}$ cells/well (subconfluent).

Reagents. TRD (Taurolin ${ }^{\circledR} 2 \%$, Boehringer Ingelheim, Germany) containing 5\% Povidon was used as supplied by the manufacturer. A 5\% Povidon solution (K16 Povidon, generously provided by Geistlich Pharma AG, Wolhusen, Switzerland) was applied in equal volume and served as a control for the TRD group. Recombinant human TRAIL/ Apo2L (Bender MedSystems, Vienna, Austria) was dissolved in distilled water according to the manufacturer's instructions. Distilled water served as a control for TRAIL and was applied in equal volume.

Dose-finding study. Cells were incubated with TRD (10, 50, $100,250$ and $500 \mu \mathrm{mol} / \mathrm{l})$ or recombinant human TRAIL $(50,100,250$ and $500 \mathrm{ng} / \mathrm{ml})$ and the respective controls (Povidon/ $\mathrm{H}_{2} \mathrm{O}$ ) for $1,3,6,12,24$ and $48 \mathrm{~h}$ to identify the most effective single concentrations and the time dependency of the effects. All experiments were repeated with 3 passages.

Additionally different concentrations of TRAIL (10, 100, 250 and $500 \mathrm{ng} / \mathrm{ml}$ ) were combined with TRD $100 \mu \mathrm{mol} / 1$ in another experiment for $1,3,6,12,24$ and $48 \mathrm{~h}$ to quantitate the effects of different TRAIL concentrations when combined with TRD. All experiments were repeated with 3 passages.

The most effective single concentrations of TRD and TRAIL were then used as single substances and in combination to identify a possibly synergistic effect. Three, 6 and $12 \mathrm{~h}$ were chosen as time points. All experiments were repeated with 3 passages. Cells for gene expression were harvested after $12 \mathrm{~h}$, representing the time of maximal apoptosis.

Flow cytometry analysis. At the indicated incubation time, floating cells were collected together with the supernatant and adherent cells which were harvested by trypsinization. Cells were sedimented by centrifugation, resuspended in $195 \mu 1$ binding buffer (Bender MedSystems) and incubated with $5 \mu \mathrm{l}$ Annexin V-FITC (BD Biosciences, Heidelberg, Germany) and $10 \mu \mathrm{l}$ propidium iodide (PI) (Bender MedSystems) following the manufacturer's manual. Cells were analyzed immediately using a FACS flow cytometer (FACS Calibur BD Biosciences). For each measurement, 20,000 cells were counted. Dot plots and histograms were analyzed by CellQuest Pro software (BD Biosciences). Annexin V positive cells were considered apoptotic; Annexin V and PI positive cells were identified as necrotic. Annexin V and PI negative cells were termed viable. 
Cell morphology. Morphology of adherent cells and cells suspended in culture medium was studied and documented using a phase contrast microscope, Zeiss Axiovert 25 (Karl Zeiss, Jena, Germany).

TUNEL assay. Apoptosis was evaluated by terminal deoxynucleotidyl transferase-mediated dUTP-nick end-labeling (TUNEL) using the in situ cell Death detection Kit ${ }^{\circledR}$ (Roche Applied Science, Mannheim, Germany) according to the manufacturer's instructions and analyzed by fluorescence microscopy (Leica DM4000B, Leica Microsystems, Nussloch, Germany).

Statistical analysis. Results of FACS analysis for percentages of viable, apoptotic and necrotic cells are expressed as means \pm SEM of at least 3 independent experiments with consecutive passages. In this study, comparisons between experimental groups (single agent application in different doses and single agents versus combined treatment at various time-points) were performed using repeated measures analysis of variance (ANOVA) over all time points. p-values $\leq 0.05$ were considered as statistically significant and indicated in the figures as follows: ${ }^{* *} \mathrm{p} \leq 0.001,{ }^{* *} \mathrm{p} \leq 0.005$ and ${ }^{*} \mathrm{p} \leq 0.05$.

Oligonucleotide microarray analysis. Total RNA was purified from the cells after incubation with the different substances for $12 \mathrm{~h}$ using the RNeasy KIT from Qiagen (Hilden, Germany), as specified by the manufacturer. RNA integrity was assessed using the Agilent 2100 Bioanalyzer (Agilent Technologies).

For microarray analyses we used the Affymetrix GeneChip platform employing a standard protocol for sample preparation and microarray hybridization. Total RNA $(5 \mu \mathrm{g})$ was converted into biotinylated cRNA according to the Affymetrix standard protocol version 2, purified, fragmented and hybridized to HG-U133Plus_2.0 microarrays (Affymetrix). The arrays were washed and stained according to the manufacturer's recommendation and finally scanned in a GeneChip scanner 3000 (Affymetrix).

Array images were processed to determine signals and detection calls (Present, Absent, Marginal) for each probe set using the Affymetrix GCOS1.4 software (MAS 5.0 statistical algorithm). Arrays were scaled across all probesets to an average intensity of 1000 to compensate for variations in the amount and quality of the cRNA samples and other experimental variables of non-biological origin. Pairwise comparisons of treated versus control samples were carried out with GCOS1.4, which calculates the significance (change p-value) of each change in gene expression based on a Wilcoxon ranking test. To limit the number of false positives, we restricted further target identification to those probe sets, which received at least one present detection call in the treated/control pair. Probe sets exhibiting a significant increase or decrease were identified by filtering using the Affymetrix Data Mining Tool 3.0.

\section{Results}

TRD induces apoptotic cell death in esophageal cancer cells. Concentrations below $100 \mu \mathrm{mol} / 1$ (10 and $50 \mu \mathrm{mol} / \mathrm{l})$
TRD
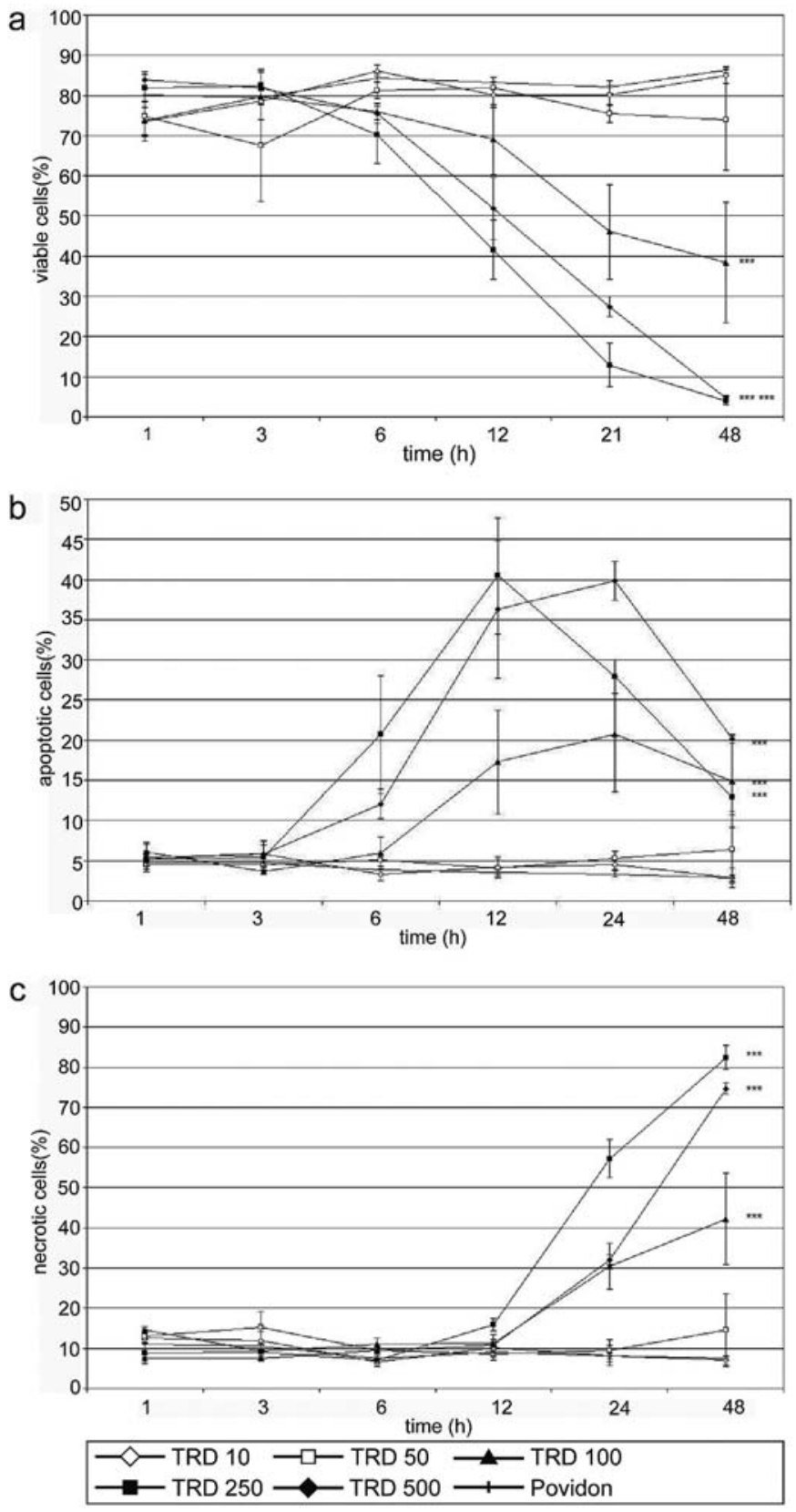

Figure 1. Effects of taurolidine (TRD) on viability, apoptosis and necrosis in KYSE 270 cells measured by FACS analysis: KYSE 270 cells were incubated with TRD in the concentrations indicated and with Povidon $5 \%$ (control) for 1-48 $\mathrm{h}$. The percentages of viable (a), apoptotic (b) and necrotic cells (c) were determined by FACS analysis for Annexin V-FITC and propidium iodide. Values are means \pm SEM of 3 independent experiments with consecutive passages ${ }^{* * *} \mathrm{p} \leq 0.001$ compared to the control group, repeated measures ANOVA).

did not lead to significant apoptosis or necrosis, even after incubation for $48 \mathrm{~h}$. The higher concentrations (100, 250 and $500 \mu \mathrm{mol} / \mathrm{l}$ ) initiated apoptotic cell death after 3-6 h of incubation, reaching a maximum of detectable apoptosis between 12 and $24 \mathrm{~h}$. The highest and most early rates of apoptosis were found for a concentration of $250 \mu \mathrm{mol} / 1$ with $40 \%$ apoptotic cells after $12 \mathrm{~h}$. This concentration also led to the highest necrosis rates, with $>80 \%$ after $48 \mathrm{~h}$. At this time, only $4 \%$ of the cells were left viable (Fig.1). 
TRAIL
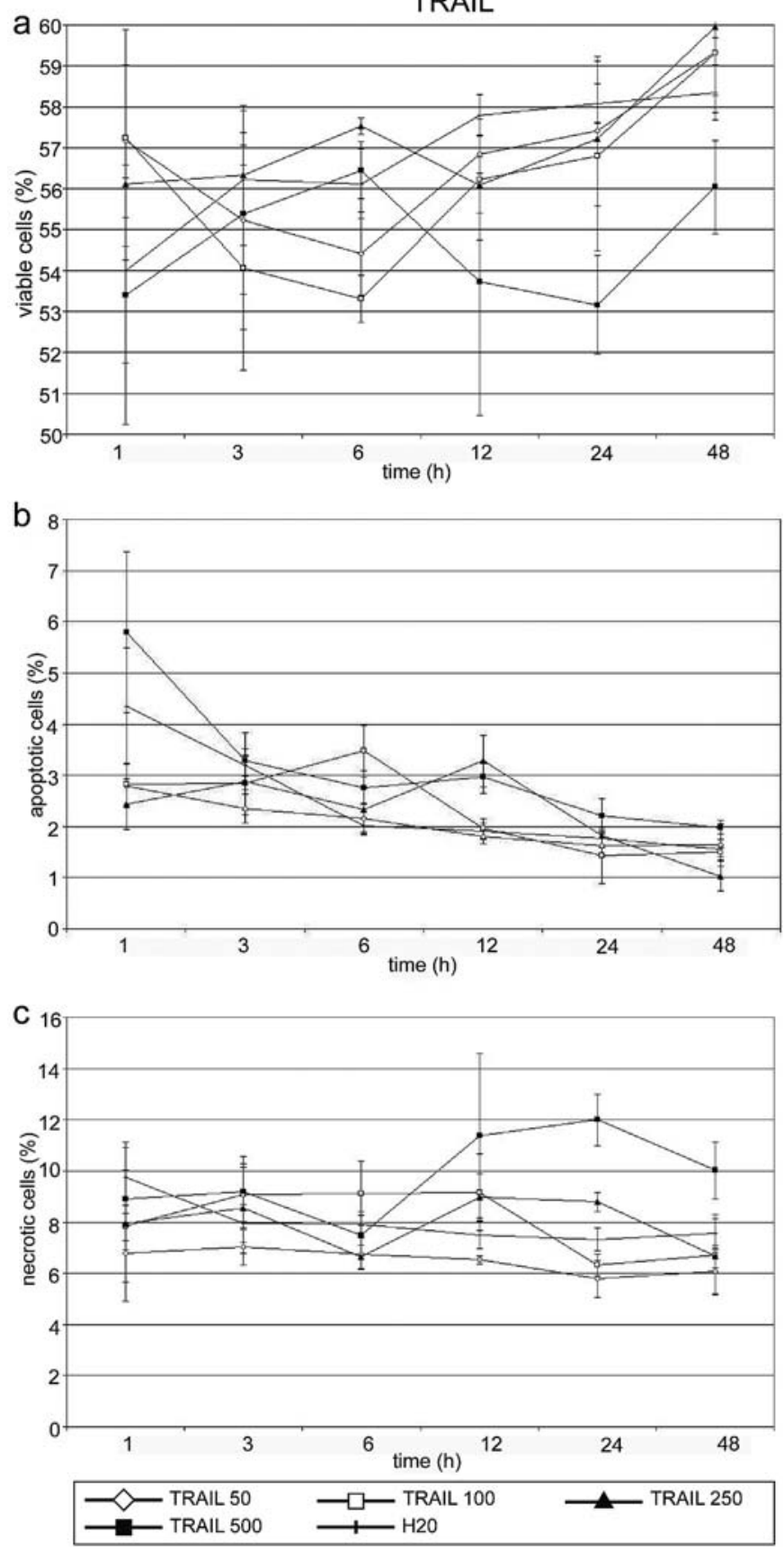

Figure 2. Effects of TRAIL on viability, apoptosis and necrosis in KYSE 270 cells measured by FACS analysis: KYSE 270 cells were incubated with TRAIL in the concentrations indicated and with $\mathrm{H}_{2} \mathrm{O}$ (control) for 1-48 h. The percentages of viable (a), apoptotic (b) and necrotic cells (c) were determined by FACS-analysis for Annexin V-FITC and propidium iodide. Values are means \pm SEM of 3 independent experiments with consecutive passages. No significant changes were detected.

TRAIL as single agent does not induce apoptotic cell death in esophageal cancer cells. The concentrations of TRAIL that were used $(50,100,250$ and $500 \mathrm{ng} / \mathrm{ml})$ did not lead to any detectable significant increase in apoptosis. After $6 \mathrm{~h}$, an increase of necrotic cells to a maximum of $12 \%$ at $24 \mathrm{~h}$ was detected with a TRAIL concentration of $500 \mathrm{ng} / \mathrm{ml}$; however, this effect was not significant. The proportion of viable cells remained above $86 \%$ after $48 \mathrm{~h}$ of incubation with the highest concentration of TRAIL (Fig. 2).
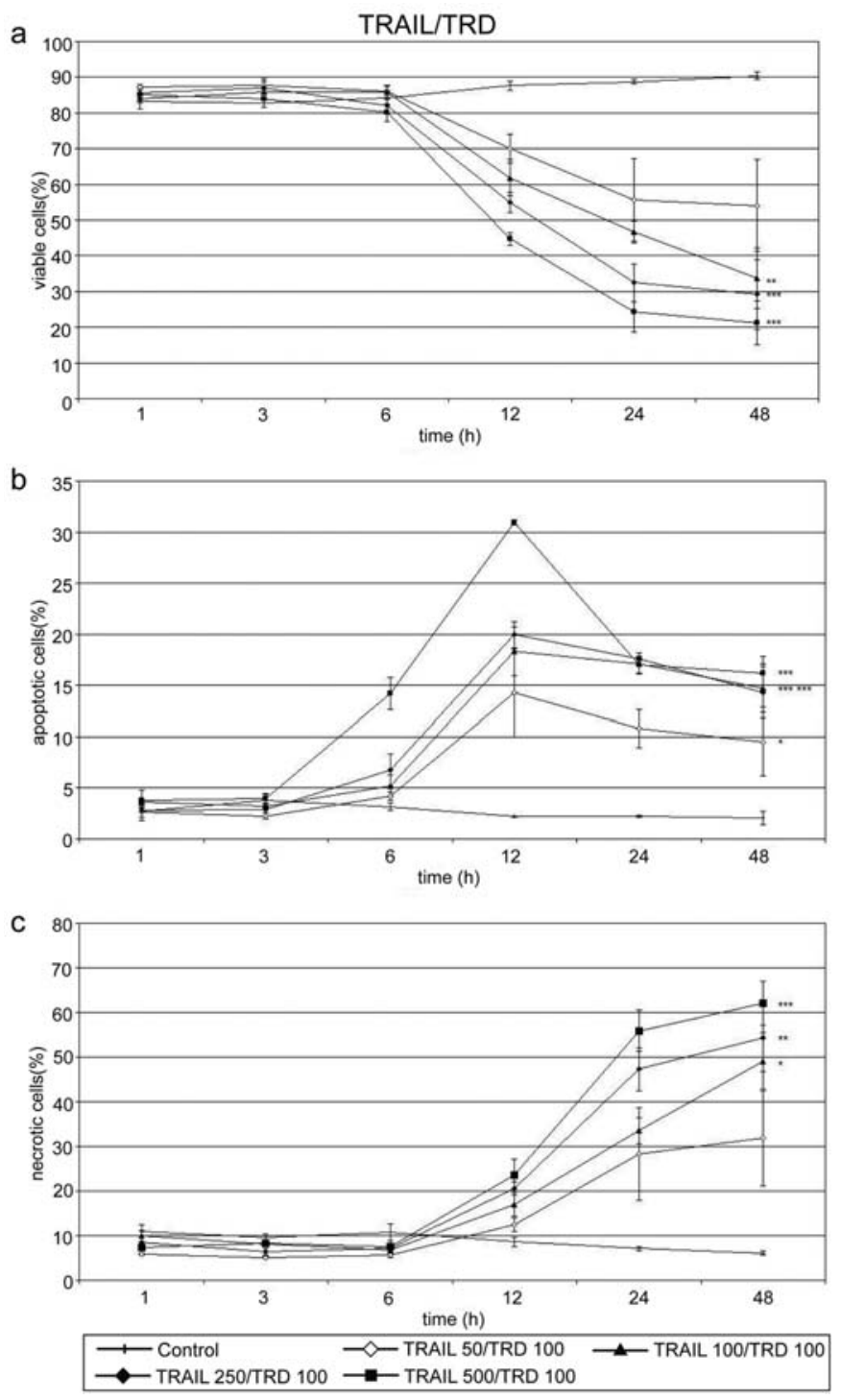

Figure 3. Effects of TRD $100 \mu \mathrm{mol} / \mathrm{ml}$ and different concentrations of TRAIL on viability, apoptosis and necrosis in KYSE 270 cells measured by FACS analysis: KYSE 270 cells were incubated with $100 \mu \mathrm{mol} / 1$ TRD and 50, 100, 250 and $500 \mathrm{ng} / \mathrm{ml}$ TRAIL as well as with Povidon $5 \%+\mathrm{H}_{2} \mathrm{O}$ (control) for 1-48 h. The percentages of viable, apoptotic and necrotic cells were determined by FACS analysis for Annexin V-FITC and propidium iodide. Values are means \pm SEM of 3 independent experiments with consecutive passages $\left({ }^{* * *} \mathrm{p} \leq 0.001,{ }^{* *} \mathrm{p} \leq 0.005\right.$ and ${ }^{*} \mathrm{p} \leq 0.05$; repeated measures ANOVA compared to control).

A combination of TRAIL and TRD amplifies apoptotic effects. When the lowest TRD concentration that was found to be effective $(100 \mu \mathrm{mol} / \mathrm{l})$ in the previous experiment was combined with different concentrations of TRAIL (50, $100,250$ and $500 \mathrm{ng} / \mathrm{ml}), 500 \mathrm{ng} / \mathrm{ml}$ of TRAIL was the most potent, reaching a maximum of almost $29 \%$ apoptotic cells after $12 \mathrm{~h}$. After $48 \mathrm{~h}, 62 \%$ of the cells were found to be necrotic and $21 \%$ were still viable (Fig. 3 ).

A combination of the most effective single doses (250 $\mu \mathrm{mol} / 1 \mathrm{TRD}$ and TRAIL $500 \mathrm{ng} / \mathrm{ml}$ ) reduces viable cells to $25 \%$ within $12 \mathrm{~h}$. Compared to the single use of $250 \mu \mathrm{mol} / 1 \mathrm{TRD}$, the addition of TRAIL $500 \mathrm{ng} / \mathrm{ml}$ doubles the effect. The reduction of viable cells as well as the induction of apoptosis was significantly increased by TRD 
TRD/TRAIL

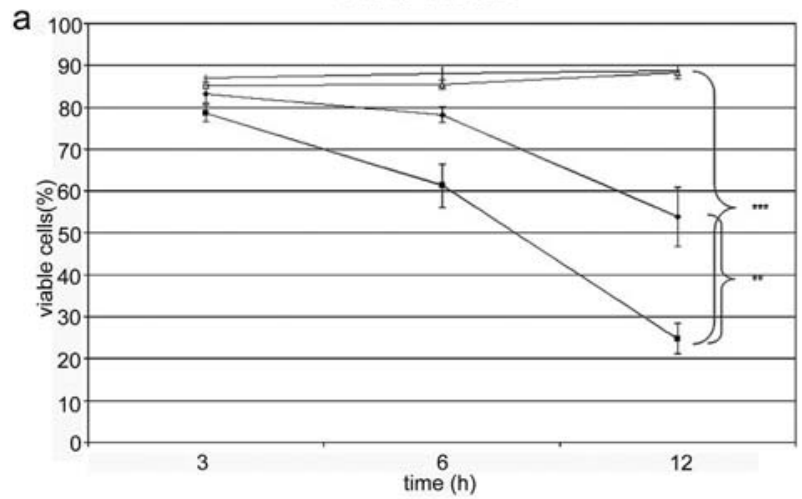

b
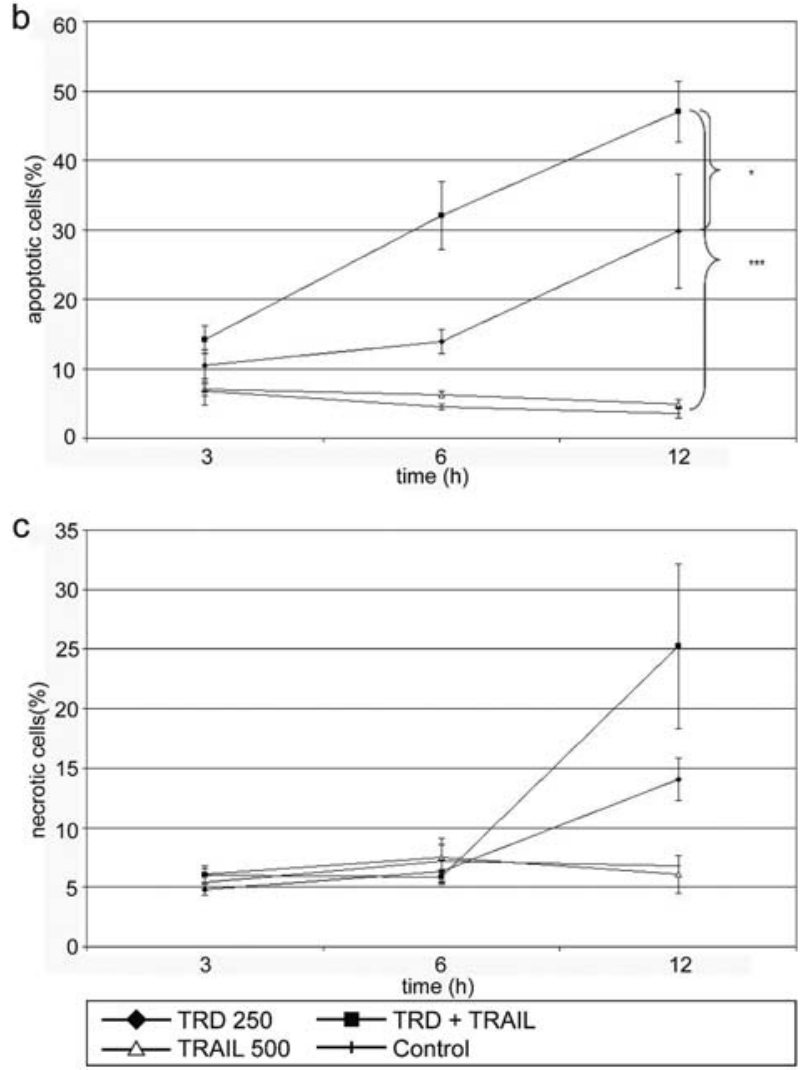

Figure 4. Effects of TRD, TRAIL and combination of both agents on viability, apoptosis and necrosis in KYSE 270 cells measured by FACS analysis: KYSE 270 cells were incubated with $250 \mu \mathrm{mol} / 1 \mathrm{TRD}$ and $500 \mathrm{ng} / \mathrm{ml}$ TRAIL alone and in combination as well as with Povidon 5\% + $\mathrm{H}_{2} \mathrm{O}$ (control) for 3 and $12 \mathrm{~h}$. The percentages of viable, apoptotic and necrotic cells were determined by FACS analysis for Annexin V-FITC and propidium iodide. Values are means \pm SEM of 3 independent experiments with consecutive passages ${ }^{* * *} \mathrm{p} \leq 0.001,{ }^{* *} \mathrm{p} \leq 0.005$ and ${ }^{*} \mathrm{p} \leq 0.05$; repeated measures ANOVA).

and TRAIL, compared to the control and compared to the single use of TRD (Fig. 4).

The dot blots of the FACS analysis demonstrated that cells were undergoing apoptotic cell death, showing Annexin V positivity in the early phases of incubation and an additional PI positivity at the later time points, representing a shift from early apoptosis to cell death and necrosis (Fig. 5).

Taurolidine and TRD/TRAIL induce morphological changes, cell detachment and TUNEL positivity. TRAIL incubation did
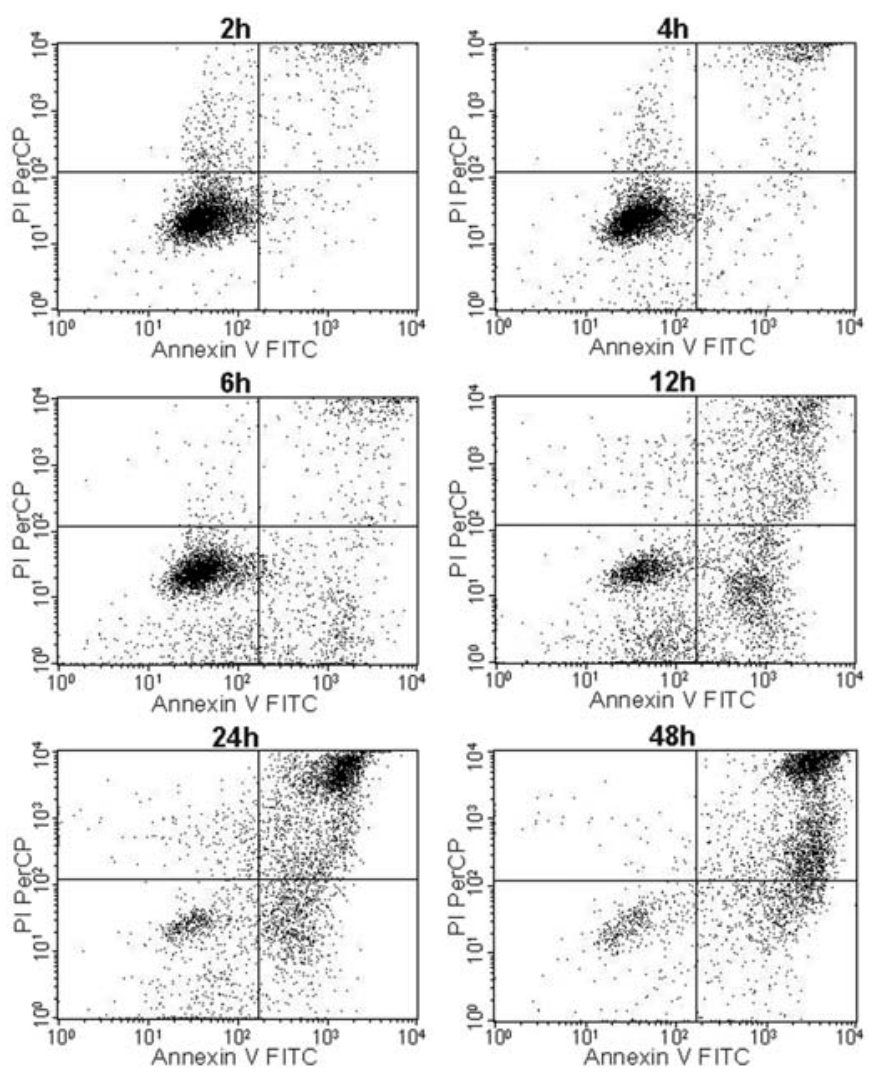

Figure 5. Representative dot plot of FACS analysis for Annexin V-FITC and propidium iodide after application of TRD $100 \mu \mathrm{mol} / 1$ and TRAIL 500 $\mathrm{ng} / \mathrm{ml}$ in KYSE 270 cells: KYSE 270 cells were incubated with 100 $\mu \mathrm{mol} / 1 \mathrm{TRD}$ and $500 \mathrm{ng} / \mathrm{ml}$ TRAIL for 2, 4, 6, 8 and $12 \mathrm{~h}$ (from upper right to lower left). Lower left quadrant: Annexin V and propidium iodide negative (viable), lower right quadrant: Annexin $\mathrm{V}$ positive and propidium iodide negative (apoptotic), upper right quadrant: Annexin $\mathrm{V}$ and propidium iodide positive (necrotic).

not change the cell morphology, or cause a detachment of the cells from the ground neither did it influence the TUNEL staining results. The combination of TRD and TRAIL resulted in disintegration of the subconfluent cell groups and shrinkage of the cells, followed by complete cell detachment (Fig. 6). TUNEL staining was negative for the controls, showed a few positive cells in the TRD treated cultures, and a noticeable increase of stained cells in the TRD/TRAIL group. Nuclear fragmentation and apoptotic bodies were also detectable in this group (Fig. 7).

Gene expression. In this experiment we selectively focussed on apoptosis related probesets. Out of 621 of those probesets 266, representing 186 apoptosis related genes showed expression changes. TRD alone induced differences in the reading of 213 probe sets, representing 154 apoptosis related genes, of which 66 were 'upregulated'; whereas TRAIL as a single substance caused changes in 12 probe sets standing for 9 genes related to apoptotic pathways, 'upregulating' 6 of them. TRD and TRAIL in combination induced overexpression of 17 and 'downregulation' of 17 (22 probe sets each) compared to TRD as single substance (Fig. 8). Due to the multitude of differential regulated genes, only a representative selection of genes is mentioned in detail. 


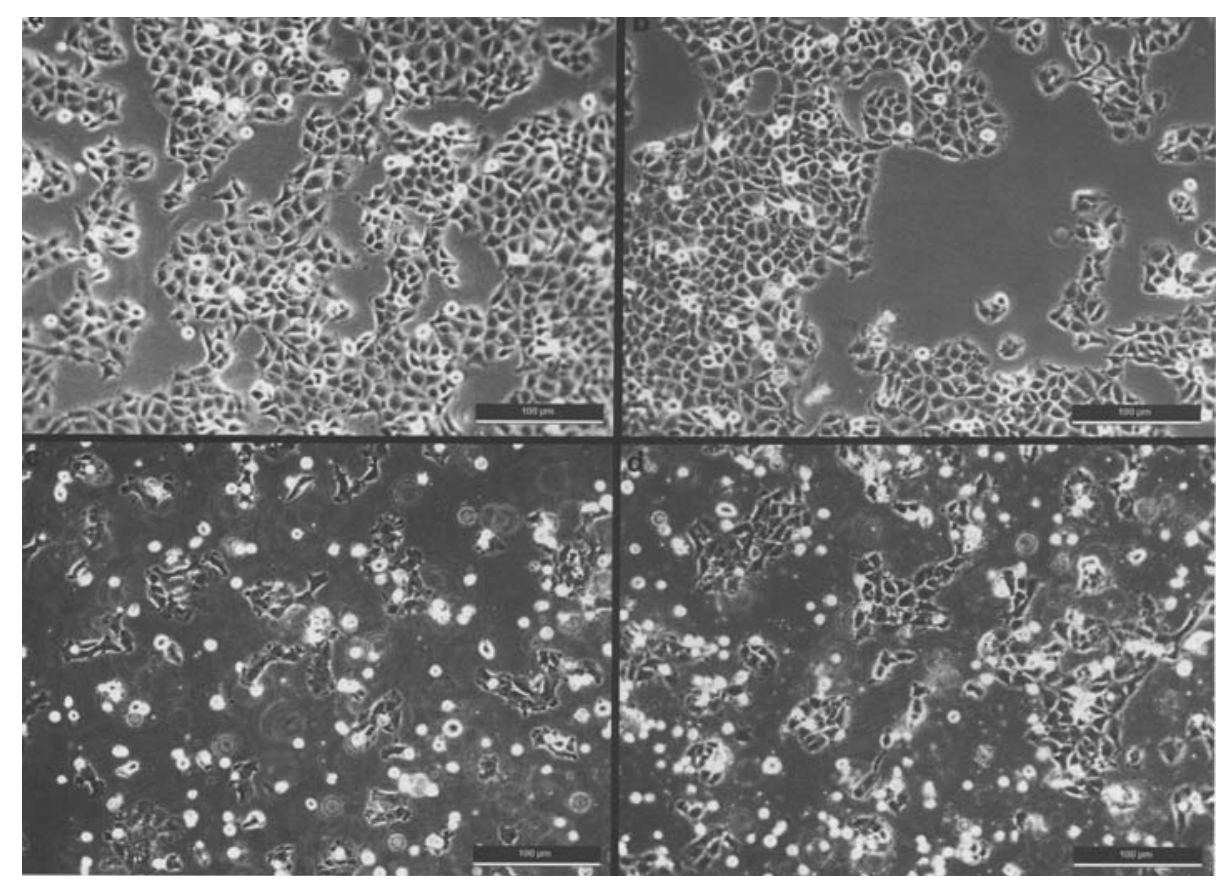

Figure 6. Representative microscopic photographs showing morphologic changes in KYSE cells induced by TRD, TRAIL and combination of both agents after $12 \mathrm{~h}$ : KYSE cells were incubated with Povidon $5 \%+\mathrm{H}_{2} \mathrm{O}$ (control) (a), $500 \mathrm{ng} / \mathrm{ml}$ TRAIL (b), $250 \mu \mathrm{mol} / \mathrm{l} \mathrm{TRD} \mathrm{(c)} \mathrm{and} \mathrm{a} \mathrm{combination} \mathrm{of} \mathrm{TRD/TRAIL}$ (d) for $12 \mathrm{~h}$. Phase contrast microscopy of cells at x20 magnification.
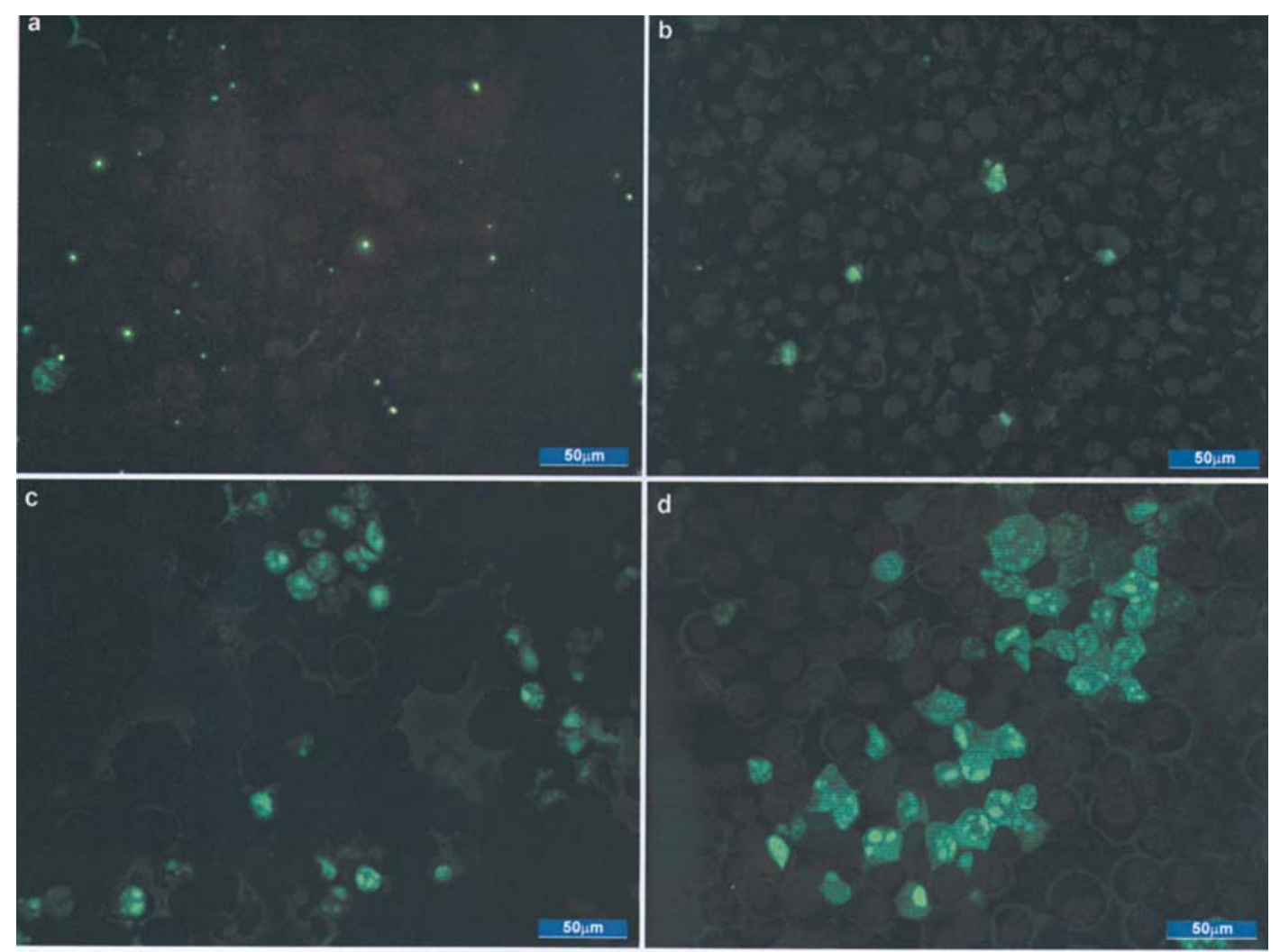

Figure 7. Representative TUNEL-assay for KYSE 270 cells after incubation with a control with Povidon $5 \%+\mathrm{H}_{2} \mathrm{O}$ (a), TRAIL $500 \mathrm{ng} / \mathrm{ml}$ (b), TRD $250 \mu \mathrm{mol} / \mathrm{l}$ (c), a combination of both agents (d) for $12 \mathrm{~h}$.

In the cells treated with TRD alone, we found the tumor necrosis factor (ligand) super-family 10 (TNFSF10/ TRAIL), the tumor necrosis factor receptor super-family $1 \mathrm{~A}$ (TNFRSF1A), TNFRSF1A-associated death domain
(TRADD), tumor necrosis factor receptor super-family 1B (TNFRSF1B), tumor necrosis factor receptor super-family 21 (TNFRSF21), Fas-associated death domain (FADD), mitogen-activated protein kinase kinase 4 (MAP2K4/c-Jun 


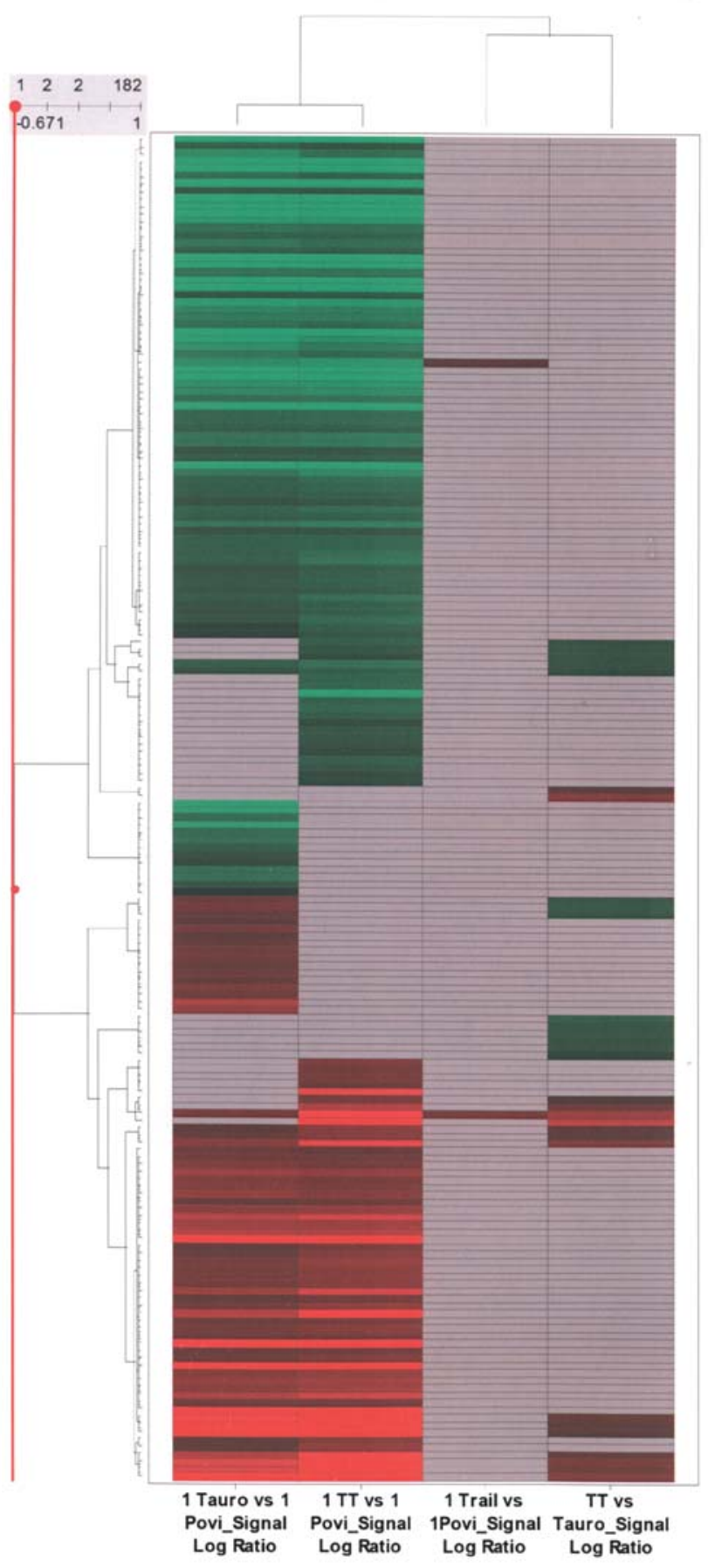

Figure 8. Overall expression patterns of reliably measured (ca+filter1) 266 probe sets associated with apoptosis out 621 apoptosis associated probe sets of the HG-U133A_2.0 chip. Horizontal rows represent individual probe sets/genes; vertical columns represent individual samples (from left to right: colour range: brightest red, signal $\log$ ratio $(\mathrm{SLR}) \geq 2$ (indicates expression level above compared sample); brightest green, SLR $\leq 2$ (indicates expression level below compared sample); black, $\mathrm{SLR}=0$ (indicates unchanged expression); grey, no reliable filter target. The dendogram at the top of the matrix indicates the degree of similarity between tumor samples; the dendogram at the left side indicates the degree of similarity among the selected genes according to their expression patterns.

N-terminal kinase kinase 1), Janus kinase 2 (JAK2), Bcl-2, $\mathrm{Bcl} 211 / \mathrm{BclxL}$, apoptotic peptidase activating factor (APAF1) and caspase- 3 'downregulated'.
Caspase-1, -8, -9, cytochrome-c, poly(ADP-ribose) polymerase family 1 (PARP1), tumor necrosis factor receptor super-family 25 (TNFRSF25), nuclear factor of kappa light polypeptide gene enhancer in B-cells inhibitor alpha (NFKBIA), growth arrest and DNA-damage-inducible gene alpha (GADD45A) and v-jun sarcoma virus 17 oncogene homolog (JUN/AP-1) were 'upregulated'.

Cells exposed to TRAIL 'downregulated' TNFSF10 (TRAIL), Bcl211 and caspase-1. Baculoviral IAP repeatcontaining 2 (BIRC2), BIRC3, tumor necrosis factor alphainduced protein 3 (TNFAIP3) and NFKBIA were 'upregulated'.

When the TRD/TRAIL incubated cells were compared to the cells only receiving TRD, DNA fragmentation factor, $45 \mathrm{kDa}$, alpha polypeptide (DFFA), TNF receptor-associated factor 3 (TRAF3) were 'downregulated'. TNFSF10 (TRAIL), NFKBIA and JUN/AP-1 were 'upregulated'. A summary of all genes associated with apoptosis by Gene Ontology is shown in Table I.

\section{Discussion}

Taurolidine. A concentration of $100 \mu \mathrm{mol} / \mathrm{l}$ was the lowest effective to induce apoptotic cell death in squamous esophageal cancer cells. The most effective concentration (reaching the peak of apoptotic cells the earliest) was $250 \mu \mathrm{mol} / \mathrm{l}$. Apoptosis was detectable after 3-6 $\mathrm{h}$ and reached its maximum at $12 \mathrm{~h}$; it then decreased and gave way to necrosis that reached a maximum after $48 \mathrm{~h}$ with $>80 \%$. The fact that $250 \mu \mathrm{mol} / 1 \mathrm{TRD}$ was more effective than $500 \mu \mathrm{mol}$ cannot be explained but may be interpreted as an indication for an apoptotic mechanism rather than a necrotic one.

Many of the factors, 'downregulated' by TRD, belong to the TNF receptor associated death signalling pathway, such as endogenous TRAIL, TNFRSF1A, TRADD, TNFRSF1B, TNFRSF21, FADD and downstream of that pathway MAP2K4.

The receptors TNFRSF1A and TNFRSF1B are transducers of TNF action and lead to programmed cell death via TRADD and FADD activation (60). Crosstalk between TNFRSF1A and TNFRSF1B (a regularly non-apoptotic receptor lacking a death domain) via endogenous TNF was shown to induce apoptosis and activate MAP2K4 and NFKB (61-63). TNFRSF21 (Death receptor 6, DR6) a recently identified member of the TNF receptor family, induces apoptosis via a FADD-independent mechanism and can be inhibited by increased levels of Bcl-2 (64).

MAP2K4/c-Jun N-terminal kinase kinase 1, which was also 'downregulated' by TRD, is a proapoptotic factor of the JNK transcription factors cascade also being activated by the TNF receptor system (65). Another anti-apoptotic tyrosine kinase JAK2, whose blockade has already been shown to inhibit tumor growth and induce apoptosis (66) and to sensitize cells to TRAIL induced apoptosis (67), was also 'downregulated' by TRD.

The inhibition of $\mathrm{Bcl} 2$ and $\mathrm{Bcl} 211$ expression by TRD may be responsible for an increased efflux of cytochrome-c and thereby positively correlates with increased complexformation with APAF 1 and consecutive caspase-9 activation 
Table I. The table summarizes the detailed expression changes identified for 266 apoptosis-associated probe sets, representing 186 genes.

\begin{tabular}{|c|c|c|c|c|c|}
\hline Probe set & Gene symbol & TRD vs. control & TRAIL vs. control & TRD/TRAIL vs. control & TRD/TRAIL vs. TRD \\
\hline 212772_s_at & ABCA2 & 0.89 & & 0.62 & \\
\hline 202123_s_at & ABL1 & -0.79 & & -1.18 & \\
\hline 201715_s_at & ACIN1 & & & & -0.3 \\
\hline 202820_at & AHR & -1.5 & & -1.23 & \\
\hline 201012_at & ANXA1 & 0.38 & & 0.4 & \\
\hline 201301_s_at & ANXA4 & 0.79 & & 0.75 & \\
\hline 201302_at & ANXA4 & 0.69 & & & \\
\hline 200782_at & ANXA5 & 0.4 & & & \\
\hline 204859_s_at & APAF1 & -1.46 & & -1.64 & \\
\hline 201686_x_at & API5 & & & -0.76 & \\
\hline 203381_s_at & APOE & 0.64 & & 0.73 & \\
\hline 203382_s_at & APOE & 0.93 & & 1.31 & \\
\hline 200602_at & APP & 0.54 & & 0.79 & \\
\hline 201167_x_at & ARHGDIA & & & -0.44 & -0.49 \\
\hline 202511_s_at & ATG5 & -0.97 & & -1.02 & \\
\hline 202512_s_at & ATG5 & -1.42 & & -1.14 & \\
\hline 202686_s_at & AXL & 0.93 & & 1.08 & \\
\hline 209364_at & BAD & 0.5 & & & \\
\hline 202387_at & BAG1 & 0.68 & & 0.52 & \\
\hline 202985_s_at & BAG5 & -1.65 & & -1.85 & \\
\hline 202984_s_at & BAG5 & -0.77 & & & \\
\hline 203685_at & BCL2 & -1.77 & & -1.99 & \\
\hline 215037_s_at & BCL2L1 & -1.56 & -0.29 & -1.02 & \\
\hline 206665_s_at & BCL2L1 & -1.17 & & -1.11 & \\
\hline 212312_at & BCL2L1 & -0.89 & & -0.78 & \\
\hline 201084_s_at & BCLAF1 & -0.26 & & -0.55 & \\
\hline 201101_s_at & BCLAF1 & -0.78 & & -1 & \\
\hline 204493_at & BID & & & -0.64 & \\
\hline 202076_at & BIRC2 & & 0.35 & & \\
\hline 210538_s_at & BIRC3 & & 1.3 & & \\
\hline 221478_at & BNIP3L & 0.92 & & 1.06 & \\
\hline 221479_s_at & BNIP3L & 1.47 & & 1.4 & \\
\hline 200921_s_at & BTG1 & -1.13 & & -0.38 & 0.62 \\
\hline 200920_s_at & BTG1 & & & 0.78 & 0.68 \\
\hline 200935_at & CALR & & & -0.61 & -0.65 \\
\hline 209970_x_at & CASP1 & 0.95 & -0.24 & 1.04 & \\
\hline 211367_s_at & CASP1 & 0.92 & -0.36 & 1.09 & \\
\hline 211368_s_at & CASP1 & 0.9 & -0.39 & 1.09 & \\
\hline 211366_x_at & CASP1 & 0.96 & & 0.89 & \\
\hline 206011_at & CASP1 & & -0.63 & & \\
\hline 202763_at & CASP3 & -1.07 & & -1.12 & \\
\hline 213373_s_at & CASP8 & & 0.33 & -1.05 & \\
\hline 203984_s_at & CASP9 & 0.43 & & 0.56 & \\
\hline 210916_s_at & CD44 /// MAPK10 & & & -0.52 & \\
\hline 202284_s_at & CDKN1A & 0.87 & & 1.03 & \\
\hline 200021_at & CFL1 & 0.35 & & 0.71 & \\
\hline 201953_at & CIB1 & 0.68 & & 0.64 & \\
\hline 214683_s_at & CLK1 & 1.16 & & 1.37 & \\
\hline 203229_s_at & CLK2 & & & & 0.83 \\
\hline 203804_s_at & CROP & -0.29 & & & \\
\hline 202329_at & CSK & -0.16 & & & \\
\hline
\end{tabular}


Table I. Continued.

\begin{tabular}{|c|c|c|c|c|c|}
\hline Probe set & Gene symbol & TRD vs. control & TRAIL vs. control & TRD/TRAIL vs. control & TRD/TRAIL vs. TRD \\
\hline 202468_s_at & CTNNAL1 & 0.38 & & & \\
\hline 200838_at & CTSB & 0.5 & & 0.57 & \\
\hline 200839_s_at & CTSB & 0.61 & & 0.84 & \\
\hline 203079_s_at & CUL2 & -1.11 & & -1.27 & \\
\hline 201370_s_at & CUL3 & -0.48 & & -0.72 & \\
\hline 201371_s_at & CUL3 & -0.55 & & -0.79 & \\
\hline 201423_s_at & CUL4A & -0.67 & & -1.16 & -0.41 \\
\hline 201424_s_at & CUL4A & & & -0.34 & \\
\hline 203532_x_at & CUL5 & -0.69 & & -0.94 & \\
\hline 203531_at & CUL5 & & & -0.32 & \\
\hline 208905_at & CYCS & 0.43 & & 0.6 & \\
\hline 200046_at & DAD1 & 0.55 & & 0.52 & \\
\hline 203139_at & DAPK1 & & & -0.99 & \\
\hline 202262_x_at & DDAH2 & 1.19 & & & \\
\hline 1007_s_at & DDR1 & 0.53 & & 0.65 & \\
\hline 207169_x_at & DDR1 & 0.63 & & 0.92 & \\
\hline 208779_x_at & DDR1 & 0.61 & & 0.85 & \\
\hline 210749_x_at & DDR1 & 0.56 & & 0.74 & \\
\hline 202480_s_at & DEDD & -0.61 & & -0.67 & \\
\hline 203277_at & DFFA & & & & -0.41 \\
\hline 206752_s_at & DFFB & & & -0.42 & \\
\hline 203187_at & DOCK1 & 0.49 & & & \\
\hline 201041_s_at & DUSP1 & 2.01 & & 2.33 & 0.37 \\
\hline 221563_at & DUSP10 & -2.22 & & -1.95 & \\
\hline 202703_at & DUSP11 & -1.03 & & -0.9 & \\
\hline 218576_s_at & DUSP12 & -0.63 & & -0.77 & \\
\hline 204794_at & DUSP2 & -1.12 & & & \\
\hline 201537_s_at & DUSP3 & -0.78 & & -1.2 & \\
\hline 204014_at & DUSP4 & -0.68 & & -0.39 & \\
\hline 204015_s_at & DUSP4 & -0.84 & & -1.02 & \\
\hline 209457_at & DUSP5 & -1.53 & 0.36 & -1.68 & \\
\hline 208892_s_at & DUSP6 & & & 0.7 & \\
\hline 2028_s_at & E2F1 & -0.39 & & -0.52 & \\
\hline 201983_s_at & EGFR & 0.56 & & 0.45 & \\
\hline 201984_s_at & EGFR & & & & -0.23 \\
\hline 210984_x_at & EGFR & & & & -0.62 \\
\hline 211607_x_at & EGFR & & & & -0.46 \\
\hline 201231_s_at & ENO1 & & & 0.62 & 0.33 \\
\hline 202221_s_at & EP300 & -1.56 & & -1.04 & \\
\hline 203499_at & ЕРНA2 & & & -0.42 & \\
\hline 206070_s_at & EPHA3 & -3.48 & & & \\
\hline 1438_at & EPHB3 & -1.06 & & -1.11 & \\
\hline 202176_at & ERCC3 & & & -0.68 & \\
\hline 209009_at & ESD & 0.93 & & 0.83 & \\
\hline 215096_s_at & ESD & 1.2 & & 1.24 & \\
\hline 202535_at & FADD & -2.92 & & -2.98 & \\
\hline 215719_x_at & FAS & -1.17 & & -1.05 & \\
\hline 216252_x_at & FAS & -1.62 & & -1.27 & \\
\hline 215404_x_at & FGFR1 & & & 1.75 & 1.33 \\
\hline 222164_at & FGFR1 & 0.66 & & 0.94 & \\
\hline 210973_s_at & FGFR1 & & & -0.32 & \\
\hline 203638_s_at & FGFR2 & -2.63 & & -2.01 & \\
\hline
\end{tabular}


Table I. Continued.

\begin{tabular}{|c|c|c|c|c|c|}
\hline Probe set & Gene symbol & TRD vs. control & TRAIL vs. control & TRD/TRAIL vs. control & TRD/TRAIL vs. TRD \\
\hline 203639_s_at & FGFR2 & -4.77 & & -4.16 & \\
\hline 208228_s_at & FGFR2 & -2.09 & & -1.65 & \\
\hline 211401_s_at & FGFR2 & -3.49 & & & \\
\hline 204579_at & FGFR4 & 0.89 & & 0.94 & \\
\hline 211237_s_at & FGFR4 & & & & -0.45 \\
\hline 202723_s_at & FOXO1A & -0.45 & & -1.04 & \\
\hline 202724_s_at & FOXO1A & -3.66 & & -2.14 & \\
\hline 204132_s_at & FOXO3A & -0.87 & & -0.96 & \\
\hline 204131_s_at & FOXO3A & -0.5 & & & \\
\hline 201636_at & FXR1 & & & -0.33 & \\
\hline 210105_s_at & FYN & -0.36 & & & \\
\hline 208926_at & FYN /// NEU1 & 1.33 & & 1.43 & \\
\hline 203725_at & GADD45A & 2.44 & & 2.53 & \\
\hline 200824_at & GSTP1 & 0.48 & & 0.83 & \\
\hline 208018_s_at & $\mathrm{HCK}$ & 1 & & 0.98 & \\
\hline 202389_s_at & HD & 0.64 & & 0.89 & \\
\hline 201209_at & HDAC1 & 0.65 & & 0.82 & \\
\hline 220085_at & HELLS & 0.54 & & & \\
\hline 200679_x_at & HMGB 1 & 0.49 & & 0.52 & \\
\hline 200680_x_at & HMGB1 & & & 0.64 & \\
\hline 206864_s_at & HRK & & & 1.2 & 0.52 \\
\hline 200599_s_at & HSP90B1 & 0.41 & & 0.66 & \\
\hline 200598_s_at & HSP90B1 & 0.38 & & & \\
\hline 200799_at & HSPA1A & 1.11 & & 1.6 & 0.48 \\
\hline 200800_s_at & HSPA1A /// HSPA1B & 1.61 & & 2.05 & 0.42 \\
\hline 202581_at & HSPA1B & 1.76 & & 2.15 & 0.35 \\
\hline 200692_s_at & HSPA9B & & & -0.3 & -0.34 \\
\hline 200691_s_at & HSPA9B & & & & -0.34 \\
\hline 201841_s_at & HSPB1 /// MEIS3 & 0.92 & & 1.08 & \\
\hline 200806_s_at & HSPD1 & -0.2 & & -0.57 & \\
\hline 201631_s_at & IER3 & 1.44 & & 2.04 & 0.65 \\
\hline 203627_at & IGF1R & -0.67 & & -0.6 & \\
\hline 203628_at & IGF1R & 0.61 & & & \\
\hline 202531_at & IRF1 & -1.14 & & & \\
\hline 203275_at & IRF2 & -2.35 & & -2.64 & \\
\hline 208436_s_at & IRF7 & 1.95 & & 2.48 & \\
\hline 205841_at & JAK2 & -3.7 & & & \\
\hline 201464_x_at & JUN & 1.47 & & 2.21 & 0.51 \\
\hline 201465_s_at & JUN & 2.16 & & 3 & 0.71 \\
\hline 201466_s_at & JUN & 0.91 & & 1.55 & 0.67 \\
\hline 213281_at & JUN & 2.16 & & 2.9 & \\
\hline 205051_s_at & KIT & -3.9 & & -5.07 & \\
\hline 201030_x_at & LDHB & & & 0.57 & \\
\hline 201105_at & LGALS1 & 1.06 & & 1.49 & \\
\hline 202625_at & LYN & -1.1 & & -1.1 & \\
\hline 202626_s_at & LYN & -0.43 & & -0.61 & \\
\hline 210754_s_at & LYN & -0.62 & & -1.09 & \\
\hline 203265_s_at & MAP2K4 & -3.27 & & -3.04 & \\
\hline 203266_s_at & MAP2K4 & -3.37 & & -3.59 & \\
\hline 203836_s_at & MAP3K5 & -0.24 & & -0.75 & \\
\hline 200796_s_at & MCL1 & -1.86 & & -1.81 & \\
\hline 200797_s_at & MCL1 & -0.59 & & -0.78 & \\
\hline
\end{tabular}


Table I. Continued.

\begin{tabular}{|c|c|c|c|c|c|}
\hline Probe set & Gene symbol & TRD vs. control & TRAIL vs. control & TRD/TRAIL vs. control & TRD/TRAIL vs. TRD \\
\hline 200798_x_at & MCL1 & -0.86 & & -0.96 & \\
\hline 217373_x_at & MDM2 & 1.23 & & 1.88 & \\
\hline 203510_at & MET & -2.3 & & -2.15 & \\
\hline 211599_x_at & MET & -2.47 & & -2.47 & \\
\hline 213816_s_at & MET & -0.79 & & -0.72 & \\
\hline 213807_x_at & MET & & & -2.98 & \\
\hline 202431_s_at & MYC & -2.93 & & -2.71 & \\
\hline 201502_s_at & NFKBIA & 0.63 & 0.64 & 1.62 & 1 \\
\hline 201577_at & NME1 & 0.49 & & & \\
\hline 201865_x_at & NR3C1 & -1.13 & & -1.33 & \\
\hline 201866_s_at & NR3C1 & -2.79 & & -2.76 & \\
\hline 211671_s_at & NR3C1 & -1.11 & & -1.37 & \\
\hline 216321_s_at & NR3C1 & -2.41 & & -2.03 & \\
\hline 214680_at & NTRK2 & -0.41 & & -0.76 & \\
\hline 202153_s_at & NUP62 & -1.43 & & -1.54 & \\
\hline 201831_s_at & PAK1 /// VDP & 0.66 & & & -0.58 \\
\hline 201832_s_at & PAK1 /// VDP & 0.57 & & & \\
\hline 208644_at & PARP1 & 0.47 & & & \\
\hline 204004_at & PAWR & & & -0.5 & -0.47 \\
\hline 204005_s_at & PAWR & & & -0.28 & \\
\hline 200787_s_at & PEA15 & 0.54 & & & -0.5 \\
\hline 200788_s_at & PEA15 & 0.81 & & 0.72 & \\
\hline 200659_s_at & PHB & -0.5 & & -0.51 & \\
\hline 209019_s_at & PINK1 & 0.5 & & 0.64 & \\
\hline 203966_s_at & PPM1A & & & -0.86 & \\
\hline 209296_at & PPM1B & -2.25 & & -2.4 & \\
\hline 213225_at & PPM1B & -1.1 & & & \\
\hline 204566_at & PPM1D & -1.46 & & -1.4 & \\
\hline 37384_at & PPM1F & 0.68 & & 0.62 & \\
\hline 203063_at & PPM1F & 0.98 & & & \\
\hline 200913_at & PPM1G & -0.62 & & -1.01 & \\
\hline 201407_s_at & PPP1CB & 1.04 & & 1.07 & \\
\hline 201408_at & PPP1CB & 0.56 & & & \\
\hline 201409_s_at & PPP1CB & 0.74 & & & \\
\hline 200726_at & PPP1CC & -0.8 & & -1.03 & \\
\hline 202014_at & PPP1R15A & 3.74 & & 4.23 & \\
\hline 205478_at & PPP1R1A & 0.37 & & 0.88 & \\
\hline 204554_at & PPP1R3D & -1.82 & & -1.72 & \\
\hline 208652_at & PPP2CA & -0.59 & & -0.68 & \\
\hline 215628_x_at & PPP2CA & & & 1.55 & \\
\hline 202884_s_at & PPP2R1B & -0.52 & & -0.45 & \\
\hline 202886_s_at & PPP2R1B & -0.69 & & -0.85 & \\
\hline 202883_s_at & PPP2R1B & & & -0.96 & \\
\hline 202313_at & PPP2R2A & -0.35 & & -0.73 & -0.28 \\
\hline 207749_s_at & PPP2R3A & & & -0.8 & -0.39 \\
\hline 202425_x_at & PPP3CA & 0.82 & & 0.98 & \\
\hline 208932_at & PPP4C & 0.49 & & & -0.41 \\
\hline 203460_s_at & PSEN1 & -0.34 & & -0.42 & \\
\hline 204053_x_at & PTEN & -0.44 & & -0.5 & \\
\hline 204054_at & PTEN & -1.1 & & -1.01 & \\
\hline 208820_at & PTK2 & -0.44 & & -0.78 & \\
\hline 207821_s_at & PTK2 & & & -0.8 & \\
\hline
\end{tabular}


Table I. Continued.

\begin{tabular}{|c|c|c|c|c|c|}
\hline Probe set & Gene symbol & TRD vs. control & TRAIL vs. control & TRD/TRAIL vs. control & TRD/TRAIL vs. TRD \\
\hline 206482_at & PTK6 & & & 0.61 & \\
\hline 207011_s_at & PTK7 & 0.54 & & & \\
\hline 204021_s_at & PURA & & & & 0.41 \\
\hline 203223_at & RABEP1 & & & -0.72 & \\
\hline 200607_s_at & RAD21 & -0.73 & & -0.9 & \\
\hline 201244_s_at & RAF1 & -1.17 & & -1.51 & \\
\hline 203749_s_at & RARA & -1.08 & & & \\
\hline 209878_s_at & RELA & -0.4 & & -0.62 & \\
\hline 209941_at & RIPK1 & -1.61 & & -1.71 & \\
\hline 209544_at & RIPK2 & -0.73 & & & \\
\hline 209545_s_at & RIPK2 & -1.07 & & & \\
\hline 201257_x_at & RPS3A & 0.41 & & 0.8 & 0.39 \\
\hline 200099_s_at & $\begin{array}{l}\text { RPS3A /// } \\
\text { LOC439992 }\end{array}$ & 0.45 & & 0.79 & 0.38 \\
\hline 201628_s_at & RRAGA & -1.23 & & -0.96 & \\
\hline 204197_s_at & RUNX3 & -1.31 & & -1.26 & \\
\hline 01844_s_at & RYBP & -1.01 & & -0.97 & \\
\hline 201845_s_at & RYBP & -2.42 & & -2.49 & \\
\hline 201846_s_at & RYBP & -0.98 & & -0.84 & \\
\hline 216976_s_at & RYK & & & -0.76 & -0.56 \\
\hline 200051_at & SART1 & 0.58 & & & \\
\hline 201819_at & SCARB1 & 0.41 & & & -0.38 \\
\hline 203528_at & SEMA4D & -0.81 & & -0.95 & \\
\hline 214882_s_at & SFRS2 & & & & 0.55 \\
\hline 201739_at & SGK & -0.39 & & & \\
\hline 202980_s_at & SIAH1 & -2.01 & & -1.56 & \\
\hline 202981_x_at & SIAH1 & -2.23 & & -2.32 & \\
\hline 203489_at & SIVA & -0.19 & & -0.22 & \\
\hline 200071_at & SMNDC1 & -0.88 & & -0.9 & \\
\hline 201086_x_at & $\mathrm{SON}$ & -1.46 & & -1.83 & \\
\hline 202693_s_at & STK17A & -2.22 & & -2.22 & \\
\hline 202695_s_at & STK17A & -1.01 & & -1 & \\
\hline 207540_s_at & SYK & -0.86 & & -0.59 & \\
\hline 200804_at & TEGT & 0.6 & & & \\
\hline 202039_at & TIAF1 /// MYO18A & 0.63 & & & \\
\hline 202405_at & TIAL1 & & & -0.87 & \\
\hline 202406_s_at & TIAL1 & -0.18 & & & \\
\hline 201149_s_at & TIMP3 & & & -0.88 & \\
\hline 202644_s_at & TNFAIP3 & 1.5 & 0.68 & 1.5 & \\
\hline 207643_s_at & TNFRSF1A & -2.84 & & -2.93 & \\
\hline 203508_at & TNFRSF1B & -2.53 & & -1.9 & \\
\hline 214581_x_at & TNFRSF21 & -1.2 & & -1.3 & \\
\hline 218856_at & TNFRSF21 & -0.91 & & -1.12 & \\
\hline 219423_x_at & TNFRSF25 & & & 1.13 & \\
\hline 202688_at & TNFSF10 & -0.14 & -0.31 & 0.48 & 0.78 \\
\hline 202687_s_at & TNFSF10 & -0.36 & & & 0.81 \\
\hline 214329_x_at & TNFSF10 & & & 0.58 & 0.85 \\
\hline 203839_s_at & TNK2 & & & 1.23 & \\
\hline 201746_at & TP53 & -0.54 & & & \\
\hline 203120_at & TP53BP2 & -1.02 & & -0.84 & \\
\hline 1729_at & TRADD & -0.45 & & -0.8 & \\
\hline 221571_at & TRAF3 & & & -0.29 & -0.27 \\
\hline
\end{tabular}


Table I. Continued.

\begin{tabular}{|c|c|c|c|c|c|}
\hline Probe set & Gene symbol & TRD vs. control & TRAIL vs. control & TRD/TRAIL vs. control & TRD/TRAIL vs. TRD \\
\hline 202871_at & TRAF4 & -0.6 & & & \\
\hline 201588_at & TXNL1 & -1.19 & & -1.11 & \\
\hline 205546_s_at & TYK2 & 0.65 & & 0.74 & \\
\hline 202316_x_at & UBE4B & -0.37 & & -0.58 & -0.58 \\
\hline 212533_at & WEE1 & -1.39 & & -1.28 & \\
\hline 215711_s_at & WEE1 & -1.08 & & -1.19 & \\
\hline 202932_at & YES1 & & & -0.28 & -0.32 \\
\hline 201020_at & YWHAH & -1.22 & & -1.49 & \\
\hline
\end{tabular}

Signal log ratios of the changes are given for the several samples (TRD vs. control, TRAIL vs. control, TRD/TRAIL vs. control, TRD/TRAIL vs. TRD), signal log ratio of 1 representing a 2 -fold increase, one of -1 , that the expression is half of the expression of the control group and so forth.

(68), which was 'upregulated' by TRD. These effects may outweigh the reduced expression of APAF 1, found in the TRD treated cells and represent a proapoptotic effect of TRD via the mitochondrial pathway.

TRD interacted with the mitochondrial pathway also by 'upregulation' of cytochrome-c expression, which is known to activate the caspase cascade as mentioned above. Within the TNF-receptor system TNFRSF25/DR3, a death receptor binding to FADD and thereby triggering apoptosis (69) was found to be 'upregulated'.

GADD45A, a potent inhibitor of the c-Jun N-terminal kinase (JNK) cascade and NFKB, inhibits transcription factors associated with tumor growth $(65,70-72)$ and was 'upregulated' by TRD. Additionally GADD45 may antagonize TNF-receptor mediated cytotoxicity (70). The transcriptional factor JUN, that was 'upregulated' in the TRD and the TRAIL treated cells, is known to be a product of MAP2K4-activation and to mediate apoptosis by several chemotherapeutics $(71,73)$.

TRAIL. No concentration of TRAIL as a single substance had a significant influence on the treated cells concerning apoptosis or necrosis within the observed time frame of $48 \mathrm{~h}$, indicating that KYSE 270 squamous esophageal cancer cells are primary TRAIL resistant.

Accordingly, the influence of TRAIL as a single substance on gene expression was moderate. Only caspase- 1 and Bcl211, which affect the cytochrome-c efflux in a similar way as Bcl-2 and endogenous TRAIL, were 'downregulated'. Coinciding with our gene expression profile findings, TRAIL is known to increase the expression of antiapoptotic mediators such as BIRC2/IAP2 and BIRC3/API2 in some malignant cells, probably via an inactivation of NFKB $(74,75)$. TNFAIP3, that was found to be 'upregulated' by TRAIL in our study, is an inhibitor of NFKB and may thereby promote apoptosis, but on the other hand TNFAIP3 was shown by other authors to decrease TNF-mediated apoptosis (76), leaving its specific influence unclear.

As previously shown, the members of the TNF family, such as TRAIL, also have many non-apoptotic functions $e . g$. activating transcription through NFKB and JUN/AP-1 leading to induction of immunomodulatory and inflammatory genes (77), involving TRADD and FADD, which are also known as mediators of several apoptotic pathways (78-80). Crosstalking to these other pathways and activating transcription factors may be unselective and partly explain possible toxic effects of TRAIL on non-malignant cells (81). Interestingly, TRD was shown to reduce toxicity of TNF in vivo without reducing its antitumoral activity probably by interfering not with TNF directly but with its down-stream pathway which is largely the same for TRAIL $(82,83)$. Accordingly, TRD, among other effects, inhibits the activation of NFKB, which is a potent signal trans-ducer for inflammatory cytokines, by oxidation of IкB- $\alpha$ at Met45 (40).

NFKB is activated TRADD-, TRAF3- and FADDdependently (72) and also plays a key role in the survival of tumor cells by inducing expression of anti-apoptotic genes such as $\mathrm{Bcl} 2, \mathrm{Bcl} 211$, vascular endothelial growth factor (VEGF) and X-linked inhibitor of apoptosis (XIAP). In physiological conditions, NFKB is sequestered in inactive form by inhibitory proteins such as NFKBIA (84-86).

Another indication for the relevance of NFKB for the observed TRD and TRAIL mediated apoptosis is the fact that NFKBIA was 'upregulated' by combination of TRAIL and TRAIL/TRD.

TRD/TRAIL. When TRAIL was added to TRD, we detected a highly significant increase in apoptotic and non-viable cells compared to the control and to TRD alone. The kinetics remained unchanged compared to TRD alone. TRAIL $(500 \mathrm{ng} / \mathrm{ml})$ proved to be the most effective concentration for the combined use with TRD $100 \mu \mathrm{mol} / 1$, leaving only $79 \%$ of the cells viable after $48 \mathrm{~h}$. In the direct comparison of the most potent single concentrations as mono-substance and the combination-treatment, a synergistic effect of TRAIL $(500 \mathrm{ng} / \mathrm{ml})$ and TRD $(250 \mu \mathrm{mol} / \mathrm{ml})$ with a bisection of the remaining living cells after $12 \mathrm{~h}$ was observed.

The synergistic effects of the combination of TRD and TRAIL may be caused by an activation of the same and of distinct apoptotic pathways, such as the TNF-receptor and the mitochondrial one, which, jointly triggered, result 
in an amplified response. However, the effects of the single substances and the gene expression profiles of the cells, treated with the combination TRD and TRAIL, point to NFKB as a key factor in apoptosis, mediated by these substances. When the TRD/TRAIL results were compared to TRD alone, we found endogenous TRAIL 'upregulated', whereas it was 'downregulated' by TRD and TRAIL as single substances. TRAF3 as an activator of NFKB was 'downregulated'; NFKBIA as an inhibitor of NFKB was 'upregulated'. JUN, that was 'upregulated' in the TRAIL and in the TRD/TRAIL treated cells, is known to be a product of MAP2K4-activation and to mediate apoptosis by several chemotherapeutics, but has also been associated with antiapoptotic effects $(73,87)$. While all death receptors as well as the described transcription factors can activate both apoptotic and non-apoptotic pathways, it has been widely assumed that the main physiological role of FADD-binding death receptors is to trigger apoptosis (69) and of NFKB to have mainly anti-apoptotic effects (85).

The 'downregulation' of DFFA may be associated with the TRD dependent 'downregulation' of caspase-3, which has been shown to be responsible for activation of DFFA (88). Altogether, as shown by the FACS analysis, the antiapoptotic effects of the combination therapy detected in the microarray analysis were greatly outweighed by the cell death inducing ones, suggesting that important factors for the synergistic effects may be increased TRAIL and decreased NFKB activity.

We conclude that the increased activation of the mitochondrial and the TNF-receptor associated pathway as well as the inhibition of crucial transcription factors qualify the TRD/TRAIL combination therapy for further studies, especially taking into consideration that other chemotherapeutics that could amplify the effect of TRAIL or sensitize resistant cells to TRAIL show considerable toxicity $(35,89)$. However, there is evidence that TRD may not only add to the apoptotic effect of TRAIL but also decrease its possible toxic side effects by pathway modulation.

\section{Acknowledgements}

We thank Amanda Daigeler for the English revision of this manuscript. We thank Professor W.E. Schmidt (Department of Medicine I, St. Josef Hospital, Ruhr-University of Bochum) and Professor A. Muegge (Department of Medicine II, St. Josef Hospital, Ruhr-University of Bochum) for generously supporting our studies, and Ilka Werner, Kirsten Mros and Rainer Lebert for technical assistance. This study was supported by FoRUM Project F544 E-2007 from the Ruhr-University Bochum, Germany.

\section{References}

1. Schlag PM: Randomized trial of preoperative chemotherapy for squamous cell cancer of the esophagus. The Chirurgische Arbeitsgemeinschaft Fuer Onkologie der Deutschen Gesellschaft Fuer Chirurgie Study Group. Arch Surg 127: 1446-1450, 1992.

2. Urba SG, Orringer MB, Turrisi A, Iannettoni M, Forastiere A and Strawderman M: Randomized trial of preoperative chemoradiation versus surgery alone in patients with locoregional esophageal carcinoma. J Clin Oncol 19: 305-313, 2001.
3. Malthaner RA, Wong RK, Rumble RB and Zuraw L: Neoadjuvant or adjuvant therapy for resectable esophageal cancer: a systematic review and meta-analysis. BMC Med 2: 35, 2004.

4. Bosset JF, Gignoux M, Triboulet JP, et al: Chemoradiotherapy followed by surgery compared with surgery alone in squamouscell cancer of the esophagus. N Engl J Med 337: 161-167, 1997.

5. Xiao ZF, Yang ZY, Liang J, Miao YJ, Wang M, Yin WB, Gu XZ, Zhang DC, Zhang RG and Wang LJ: Value of radiotherapy after radical surgery for esophageal carcinoma: a report of 495 patients. Ann Thorac Surg 75: 161-167, 2003.

6. Ancona E, Ruol A, Santi S, Merigliano S, Sileni VC, Koussis H, Zaninotto G, Bonavina L and Peracchia A: Only pathologic complete response to neoadjuvant chemotherapy improves significantly the long-term survival of patients with resectable esophageal squamous cell carcinoma: final report of a randomized, controlled trial of preoperative chemotherapy versus surgery alone. Cancer 91: 2165-2174, 2001.

7. Kelsen DP, Minsky B, Smith M, Beitler J, Niedzwiecki D, Chapman D, Bains M, Burt M, Heelan R and Hilaris B: Preoperative therapy for esophageal cancer: a randomized comparison of chemotherapy versus radiation therapy. J Clin Oncol 8: 1352-1361, 1990.

8. Enzinger PC and Mayer RJ: Esophageal cancer. N Engl J Med 349: 2241-2252, 2003.

9. Forastiere AA: Treatment of locoregional esophageal cancer. Semin Oncol 19: 57-63, 1992

10. Muller JM, Erasmi H, Stelzner M, Zieren U and Pichlmaier H: Surgical therapy of oesophageal carcinoma. Br J Surg 77: 845-857, 1990.

11. Badwe RA, Sharma V, Bhansali MS, Dinshaw KA, Patil PK, Dalvi N, Rayabhattanavar SG and Desai PB: The quality of swallowing for patients with operable esophageal carcinoma: a randomized trial comparing surgery with radiotherapy. Cancer 85: 763-768, 1999.

12. Geissler M, Schwacha H, Eggstein S, Usadel H, Harder J, Opitz O, Arnold C, Grimm CF and Blum HE: Esophageal carcinoma: non-surgical therapy. Schweiz Rundsch Med Prax 93: 2057-2064, 2004.

13. Kitamura K, Kuwano H, Watanabe M, Nozoe T, Yasuda M, Sumiyoshi K, Saku M and Sugimachi K: Prospective randomized study of hyperthermia combined with chemoradiotherapy for esophageal carcinoma. J Surg Oncol 60: 55-58, 1995.

14. Coia LR, Engstrom PF, Paul AR, Stafford PM and Hanks GE: Long-term results of infusional 5-FU, mitomycin-C and radiation as primary management of esophageal carcinoma. Int J Radiat Oncol Biol Phys 20: 29-36, 1991.

15. Nishimura Y, Suzuki M, Nakamatsu K, Kanamori S, Yagyu Y and Shigeoka H: Prospective trial of concurrent chemoradiotherapy with protracted infusion of 5-fluorouracil and cisplatin for T4 esophageal cancer with or without fistula. Int J Radiat Oncol Biol Phys 53: 134-139, 2002.

16. Ishida K, Ando N, Yamamoto S, Ide H and Shinoda M: Phase II study of cisplatin and 5-fluorouracil with concurrent radiotherapy in advanced squamous cell carcinoma of the esophagus: a Japan Esophageal Oncology Group (JEOG)/Japan Clinical Oncology Group trial (JCOG9516). Jpn J Clin Oncol 34: 615-619, 2004.

17. Herskovic A, Martz K, Al-Sarraf M, Leichman L, Brindle J, Vaitkevicius V, Cooper J, Byhardt R, Davis L and Emami B: Combined chemotherapy and radiotherapy compared with radiotherapy alone in patients with cancer of the esophagus. N Engl J Med 326: 1593-1598, 1992.

18. Kaneko K, Ito H, Konishi K, et al: Definitive chemoradiotherapy for patients with malignant stricture due to T3 or T4 squamous cell carcinoma of the oesophagus. Br $\mathrm{J}$ Cancer 88: 18-24, 2003.

19. Rowinsky EK: Targeted induction of apoptosis in cancer management: the emerging role of tumor necrosis factorrelated apoptosis-inducing ligand receptor activating agents. J Clin Oncol 23: 9394-9407, 2005.

20. Ashkenazi A, Pai RC, Fong S, et al: Safety and antitumor activity of recombinant soluble Apo2 ligand. J Clin Invest 104: 155-162, 1999.

21. Bouralexis S, Findlay DM and Evdokiou A: Death to the bad guys: targeting cancer via Apo2L/TRAIL. Apoptosis 10: 35-51, 2005 .

22. Fesik SW: Promoting apoptosis as a strategy for cancer drug discovery. Nat Rev Cancer 5: 876-885, 2005.

23. LeBlanc HN and Ashkenazi A: Apo2L/TRAIL and its death and decoy receptors. Cell Death Differ 10: 66-75, 2003. 
24. Walczak H, Miller RE, Ariail K, et al: Tumoricidal activity of tumor necrosis factor-related apoptosis-inducing ligand in vivo. Nat Med 5: 157-163, 1999.

25. Wiley SR, Schooley K, Smolak PJ, et al: Identification and characterization of a new member of the TNF family that induces apoptosis. Immunity 3: 673-682, 1995.

26. Bradbury J: TRAIL leads to apoptosis in acute promyelocytic leukaemia. Lancet 357: 1770, 2001

27. Cretney E, McQualter JL, Kayagaki N, Yagita H, Bernard CC, Grewal IS, Ashkenazi A and Smyth MJ: TNF-related apoptosisinducing ligand (TRAIL)/Apo2L suppresses experimental autoimmune encephalomyelitis in mice. Immunol Cell Biol 83: 511-519, 2005

28. Yagita H, Takeda K, Hayakawa Y, Smyth MJ and Okumura K: TRAIL and its receptors as targets for cancer therapy. Cancer Sci 95: 777-783, 2004

29. Pan G, Ni J, Yu G, Wei YF and Dixit VM: TRUNDD, a new member of the TRAIL receptor family that antagonizes TRAIL signalling. FEBS Lett 424: 41-45, 1998.

30. Griffith TS, Fialkov JM, Scott DL, Azuhata T, Williams RD, Wall NR, Altieri DC and Sandler AD: Induction and regulation of tumor necrosis factor-related apoptosis-inducing ligand/ Apo-2 ligand-mediated apoptosis in renal cell carcinoma. Cancer Res 62: 3093-3099, 2002.

31. Kim SH, Kim K, Kwagh JG, Dicker DT, Herlyn M, Rustgi AK, Chen Y and El-Deiry WS: Death induction by recombinant native TRAIL and its prevention by a caspase-9 inhibitor in primary human esophageal epithelial cells. J Biol Chem 279: 40044-40052, 2004.

32. Nagane M, Huang HJ and Cavenee WK: The potential of TRAIL for cancer chemotherapy. Apoptosis 6: 191-197, 2001.

33. Yeow WS, Baras A, Chua A, Nguyen DM, Sehgal SS, Schrump DS and Nguyen DM: Gossypol, a phytochemical with BH3-mimetic property, sensitizes cultured thoracic cancer cells to Apo2 ligand/tumor necrosis factor-related apoptosisinducing ligand. J Thorac Cardiovasc Surg 132: 1356-1362, 2006.

34. Naka T, Sugamura K, Hylander BL, Widmer MB, Rustum YM and Repasky EA: Effects of tumor necrosis factor-related apoptosis-inducing ligand alone and in combination with chemotherapeutic agents on patients' colon tumors grown in SCID mice. Cancer Res 62: 5800-5806, 2002.

35. Van Geelen CM, De Vries EG and De Jong S: Lessons from TRAIL-resistance mechanisms in colorectal cancer cells: paving the road to patient-tailored therapy. Drug Resist Updat 7: 345-358, 2004

36. Tsai WS, Yeow WS, Chua A, Reddy RM, Nguyen DM, Schrump DS and Nguyen DM: Enhancement of Apo2L/ TRAIL-mediated cytotoxicity in esophageal cancer cells by cisplatin. Mol Cancer Ther 5: 2977-2990, 2006.

37. Kondo K, Yamasaki S, Inoue N, Sugie T, Teratani N, Kan T and Shimada Y: Prospective antitumor effects of the combination of tumor necrosis factor-related apoptosis-inducing ligand (TRAIL) and cisplatin against esophageal squamous cell carcinoma. Surg Today 36: 966-974, 2006.

38. Teraishi F, Kagawa S, Watanabe T, Tango Y, Kawashima T, Umeoka T, Nisizaki M, Tanaka N and Fujiwara T: ZD1839 (Gefitinib, 'Iressa'), an epidermal growth factor receptor-tyrosine kinase inhibitor, enhances the anti-cancer effects of TRAIL in human esophageal squamous cell carcinoma. FEBS Lett 579: 4069-4075, 2005 .

39. Nagane M, Pan G, Weddle JJ, Dixit VM, Cavenee WK and Huang HJ: Increased death receptor 5 expression by chemotherapeutic agents in human gliomas causes synergistic cytotoxicity with tumor necrosis factor-related apoptosis-inducing ligand in vitro and in vivo. Cancer Res 60: 847-853, 2000.

40. Schuller-Levis GB and Park E: Taurine: new implications for an old amino acid. FEMS Microbiol Lett 226: 195-202, 2003.

41. Baker DM, Jones JA, Nguyen-Van-Tam JS, Lloyd JH, Morris DL, Bourke JB, Steele RJ and Hardcastle JD: Taurolidine peritoneal lavage as prophylaxis against infection after elective colorectal surgery. Br J Surg 81: 1054-1056, 1994

42. McCartney AC and Browne MK: Clinical studies on administration of taurolin in severe sepsis: a preliminary study. Prog Clin Biol Res 272: 361-371, 1988 .

43. Willatts SM, Radford S and Leitermann M: Effect of the antiendotoxic agent, taurolidine, in the treatment of sepsis syndrome: a placebo-controlled, double-blind trial. Crit Care Med 23: 1033-1039, 1995.
44. Braumann C, Henke W, Jacobi CA and Dubiel W: The tumorsuppressive reagent taurolidine is an inhibitor of protein biosynthesis. Int J Cancer 112: 225-230, 2004.

45. Calabresi P, Goulette FA and Darnowski JW: Taurolidine: cytotoxic and mechanistic evaluation of a novel antineoplastic agent. Cancer Res 61: 6816-6821, 2001.

46. Darnowski JW, Goulette FA, Cousens LP, Chatterjee D and Calabresi P: Mechanistic and antineoplastic evaluation of taurolidine in the DU145 model of human prostate cancer. Cancer Chemother Pharmacol 54: 249-258, 2004.

47. McCourt M, Wang JH, Sookhai S and Redmond HP: Taurolidine inhibits tumor cell growth in vitro and in vivo. Ann Surg Oncol 7: 685-691, 2000.

48. Nici L, Monfils B and Calabresi P: The effects of taurolidine, novel antineoplastic agent, on human malignant mesothelioma. Clin Cancer Res 10: 7655-7661, 2004.

49. Ribizzi I, Darnowski JW, Goulette FA, Akhtar MS, Chatterjee D and Calabresi P: Taurolidine: preclinical evaluation of a novel highly selective, agent for bone marrow purging. Bone Marrow Transplant 29: 313-319, 2002.

50. Shrayer DP, Lukoff H, King T and Calabresi P: The effect of Taurolidine on adherent and floating subpopulations of melanoma cells. Anticancer Drugs 14: 295-303, 2003.

51. Opitz I, Sigrist B, Hillinger S, Lardinois D, Stahel R, Weder W and Hopkins-Donaldson S: Taurolidine and povidone-iodine induce different types of cell death in malignant pleural mesothelioma. Lung Cancer 56: 327-336, 2007.

52. Walters DK, Muff R, Langsam B, Gruber P, Born W and Fuchs B: Taurolidine: a novel anti-neoplastic agent induces apoptosis of osteosarcoma cell lines. Invest New Drugs 25: 305-312, 2007.

53. Braumann C, Winkler G, Rogalla P, Menenakos C and Jacobi CA: Prevention of disease progression in a patient with a gastric cancer-re-recurrence. Outcome after intravenous treatment with the novel antineoplastic agent taurolidine. Report of a case. World J Surg Oncol 4: 34, 2006.

54. Stendel R, Scheurer L, Schlatterer K, Stalder U, Pfirrmann RW, Fiss I, Mohler H and Bigler L: Pharmacokinetics of taurolidine following repeated intravenous infusions measured by HPLC-ESI-MS/MS of the derivatives taurultame and taurinamide in glioblastoma patients. Clin Pharmacokinet 46 513-524, 2007.

55. Stendel R, Picht T, Schilling A, Heidenreich J, Loddenkemper C, Janisch W and Brock M: Treatment of glioblastoma with intravenous taurolidine. First clinical experience. Anticancer Res 24: 1143-1147, 2004

56. Han Z, Ribbizi I, Pantazis P, Wyche J, Darnowski J and Calabresi P: The antibacterial drug taurolidine induces apoptosis by a mitochondrial cytochrome c-dependent mechanism. Anticancer Res 22: 1959-1964, 2002.

57. Rodak R, Kubota H, Ishihara H, Eugster HP, Konu D, Mohler H, Yonekawa $\mathrm{Y}$ and Frei $\mathrm{K}$ : Induction of reactive oxygen intermediates-dependent programmed cell death in human malignan ex vivo glioma cells and inhibition of the vascular endothelial growth factor production by taurolidine. J Neurosurg 102 $1055-1068,2005$.

58. Jacobi CA, Menenakos C and Braumann C: Taurolidine - a new drug with anti-tumor and anti-angiogenic effects. Anticancer Drugs 16: 917-921, 2005

59. Stendel R, Scheurer L, Stoltenburg-Didinger G, Brock M and Mohler H: Enhancement of Fas-ligand-mediated programmed cell death by taurolidine. Anticancer Res 23: 2309-2314, 2003

60. D'Osualdo A, Ferlito F, Prigione I, et al: Neutrophils from patients with TNFRSF1A mutations display resistance to tumor necrosis factor-induced apoptosis: pathogenetic and clinical implications. Arthritis Rheum 54: 998-1008, 2006.

61. Weingartner M, Siegmund D, Schlecht U, Fotin-Mleczek M, Scheurich $\mathrm{P}$ and Wajant $\mathrm{H}$ : Endogenous membrane tumor necrosis factor (TNF) is a potent amplifier of TNF receptor 1-mediated apoptosis. J Biol Chem 277: 34853-34859, 2002 .

62. Hu WH, Mo XM, Walters WM, Brambilla R and Bethea JR: TNAP, a novel repressor of NF-kappaB-inducing kinase, suppresses NF-kappaB activation. J Biol Chem 279: 35975-35983, 2004

63. Soni V, Cahir-McFarland E and Kieff E: LMP1 TRAfficking activates growth and survival pathways. Adv Exp Med Biol 597: 173-187, 2007 
64. Kasof GM, Lu JJ, Liu D, Speer B, Mongan KN, Gomes BC and Lorenzi MV: Tumor necrosis factor-alpha induces the expression of DR6, a member of the TNF receptor family, through activation of NF-kappaB. Oncogene 20: 7965-7975, 2001.

65. Mikami T, Koyama T, Koyama T, Imakiire A, Yamamoto K, Furuhata M, Toyota $\mathrm{H}$ and Mizuguchi J: C-jun N-terminal kinase activation is required for apoptotic cell death induced by TNF-related apoptosis-inducing ligand plus DNA-damaging agents in sarcoma cell lines. Anticancer Res 26: 1153-1160, 2006.

66. Paner GP, Silberman S, Hartman G, Micetich KC, Aranha GV and Alkan S: Analysis of signal transducer and activator of transcription 3 (STAT3) in gastrointestinal stromal tumors. Anticancer Res 23: 2253-2260, 2003.

67. Kusaba M, Nakao K, Goto T, et al: Abrogation of constitutive STAT3 activity sensitizes human hepatoma cells to TRAILmediated apoptosis. J Hepatol (In press).

68. Li P, Nijhawan D, Budihardjo I, Srinivasula SM, Ahmad M, Alnemri ES and Wang X: Cytochrome $\mathrm{c}$ and dATP-dependent formation of Apaf-1/caspase-9 complex initiates an apoptotic protease cascade. Cell 91: 479-489, 1997.

69. Park SM, Schickel R and Peter ME: Non-apoptotic functions of FADD-binding death receptors and their signaling molecules. Curr Opin Cell Biol 17: 610-616, 2005.

70. Papa S, Zazzeroni F, Bubici C, et al: Gadd45 beta mediates the NF-kappa B suppression of JNK signalling by targeting MKK7/JNKK2. Nat Cell Biol 6: 146-153, 2004.

71. Lauricella M, Emanuele S, D'Anneo A, Calvaruso G, Vassallo B, Carlisi D, Portanova P, Vento R and Tesoriere G: JNK and AP-1 mediate apoptosis induced by bortezomib in HepG2 cells via FasL/caspase-8 and mitochondria-dependent pathways. Apoptosis 11: 607-625, 2006

72. Jin Z and El-Deiry WS: Distinct signaling pathways in TRAILversus tumor necrosis factor-induced apoptosis. Mol Cell Biol 26: 8136-8148, 2006.

73. Karin M and Chang L: AP-1-glucocorticoid receptor crosstalk taken to a higher level. J Endocrinol 169: 447-451, 2001.

74. Park SY, Billiar TR and Seol DW: IFN-gamma inhibition of TRAIL-induced IAP-2 upregulation, a possible mechanism of IFN-gamma-enhanced TRAIL-induced apoptosis. Biochem Biophys Res Commun 291: 233-236, 2002.

75. Piva R, Gianferretti P, Ciucci A, Taulli R, Belardo G and Santoro MG: 15-Deoxy-delta 12,14-prostaglandin J2 induces apoptosis in human malignant B cells: an effect associated with inhibition of NF-kappa B activity and down-regulation of anti-apoptotic proteins. Blood 105: 1750-1758, 2005.

76. Jaattela M, Mouritzen H, Elling F and Bastholm L: A20 zinc finger protein inhibits TNF and IL-1 signaling. J Immunol 156: 1166-1173, 1996.
77. Wallach D, Varfolomeev EE, Malinin NL, Goltsev YV, Kovalenko AV and Boldin MP: Tumor necrosis factor receptor and Fas signaling mechanisms. Annu Rev Immunol 17: 331-367, 1999.

78. Newton K, Kurts C, Harris AW and Strasser A: Effects of a dominant interfering mutant of FADD on signal transduction in activated T cells. Curr Biol 11: 273-276, 2001

79. Walsh CM, Wen BG, Chinnaiyan AM, O'Rourke K, Dixit VM and Hedrick SM: A role for FADD in T cell activation and development. Immunity 8: 439-449, 1998.

80. Zornig M, Hueber AO and Evan G: p53-dependent impairment of T-cell proliferation in FADD dominant-negative transgenic mice. Curr Biol 8: 467-470, 1998.

81. Kumar-Sinha C, Varambally S, Sreekumar A and Chinnaiyan AM: Molecular cross-talk between the TRAIL and interferon signaling pathways. J Biol Chem 277: 575-585, 2002.

82. Monson JR, Ramsey PS and Donohue JH: Taurolidine inhibits tumour necrosis factor (TNF) toxicity - new evidence of TNF and endotoxin synergy. Eur J Surg Oncol 19: 226-231, 1993.

83. Marcinkiewicz J, Kurnyta M, Biedron R, Bobek M, Kontny E and Maslinski W: Anti-inflammatory effects of taurine derivatives (taurine chloramine, taurine bromamine and taurolidine) are mediated by different mechanisms. Adv Exp Med Biol 583: 481-492, 2006.

84. Lin MT, Chang CC, Chen ST, Chang HL, Su JL, Chau YP and Kuo ML: Cyr61 expression confers resistance to apoptosis in breast cancer MCF-7 cells by a mechanism of NF-kappaBdependent XIAP up-regulation. J Biol Chem 279: 24015-24023, 2004.

85. Shukla S and Gupta S: Suppression of constitutive and tumor necrosis factor alpha-induced nuclear factor (NF)-kappaB activation and induction of apoptosis by apigenin in human prostate carcinoma PC-3 cells: correlation with down-regulation of NF-kappaB-responsive genes. Clin Cancer Res 10: 3169-3178, 2004.

86. Pham LV, Tamayo AT, Yoshimura LC, Lo P and Ford RJ: Inhibition of constitutive NF-kappa B activation in mantle cell lymphoma B cells leads to induction of cell cycle arrest and apoptosis. J Immunol 171: 88-95, 2003.

87. Brecht S, Kirchhof R, Chromik A, et al: Specific pathophysiological functions of JNK isoforms in the brain. Eur J Neurosci 21: 363-377, 2005.

88. Das A, Banik NL and Ray SK: Mechanism of apoptosis with the involvement of calpain and caspase cascades in human malignant neuroblastoma SH-SY5Y cells exposed to flavonoids Int J Cancer 119: 2575-2585, 2006.

89. Shankar S and Srivastava RK: Enhancement of therapeutic potential of TRAIL by cancer chemotherapy and irradiation mechanisms and clinical implications. Drug Resist Updat 7 139-156, 2004. 